$9-4-2020$

\title{
Rose-Colored Genocide: Hollywood, Harmonizing Narratives, and the Cinematic Legacy of Anne Frank's Diary in the United States
}

Nora Nunn

Duke University

Follow this and additional works at: https://digitalcommons.usf.edu/gsp

\section{Recommended Citation}

Nunn, Nora (2020) "Rose-Colored Genocide: Hollywood, Harmonizing Narratives, and the Cinematic Legacy of Anne Frank's Diary in the United States," Genocide Studies and Prevention: An International Journal: Vol. 14: Iss. 2: 65-89.

DOI:

https://doi.org/10.5038/1911-9933.14.2.1715

Available at: https://digitalcommons.usf.edu/gsp/vol14/iss2/7

This Articles is brought to you for free and open access by the Open Access Journals at Digital Commons @ University of South Florida. It has been accepted for inclusion in Genocide Studies and Prevention: An International Journal by an authorized editor of Digital Commons @ University of South Florida. For more information, please contact digitalcommons@usf.edu. 
Rose-Colored Genocide: Hollywood, Harmonizing Narratives, and the Cinematic Legacy of Anne Frank's Diary in the United States

\section{Acknowledgements}

This article benefited from the support, perspective, and suggestions of many: the anonymous peer reviewers, Priscilla Wald, James Dawes, Wesley Hogan, Aarthi Vadde, Tsitsi Jaji, Christine Ryan, Gabriella Levy, Emma Davenport, and Renée Ragin. 


\title{
Rose-Colored Genocide: Hollywood, Harmonizing Narratives, and the Cinematic Legacy of Anne Frank's Diary in the United States
}

\author{
Nora Nunn \\ Duke University \\ Durham, North Carolina, USA
}

\section{Introduction}

Concluding a film about the Holocaust on an uplifting note seems counterintuitive. Yet, more often than not, films about genocide, especially those made in Hollywood, rely precisely on what critic Dominick LaCapra calls a "harmonizing narrative," a story that provides the reader or viewer with "an unwarranted sense of spiritual uplift." ${ }^{1}$ LaCapra points to Steven Spielberg's Schindler's List as an example, citing its stubborn insistence on a Manichean goodness in the midst of atrocity. ${ }^{2}$ This phenomenon is articulated through the character of Itzhak Stern (Ben Kingsley), who proclaims to Oskar Schindler (Liam Neeson) of the eponymous document, "The list is absolute good." ${ }^{3}$ In the face of genocide, optimism proves stubborn - at least according to representations of the crime constructed by Hollywood.

But the strategy of narrative uplift concerning genocide predates Schindler's List by several decades. Indeed, perhaps the most famous case of such a harmonizing narrative is the Americanized version of the story of Anne Frank, a young girl who went into hiding in the Netherlands during World War II but was ultimately captured and exterminated in the Nazi camps. Interpretations of her diary shape-shifted in the postwar years. Throughout the 1950s, U.S. adaptations of the diary flattened and infantilized its teenage author, who had died, probably of typhus, in BergenBelsen concentration camp in 1945. ${ }^{4}$ In 1955, the diary appeared as a Broadway play. Four years later, in 1959, George Stevens, known for screwball comedies, melodramas, and Westerns such as Penny Serenade, ${ }^{5}$ The More the Merrier, ${ }^{6}$ and Giant, ${ }^{7}$ oversaw the Hollywood adaptation. ${ }^{8}$ A list of cultural taboos governed both of these U.S. productions. American publishers and producers of the play and film suppressed direct references to Judaism (such as Yom Kippur), anti-Semitism (the Nazi capture of the Jewish community in Amsterdam), and adolescent complexities (including menstruation, sexual desire, and descriptions of female anatomy). ${ }^{9}$ Such bowdlerization distracted from inconvenient truths, such as the fact that, due to bureaucratic "red tape" and "national security concerns," the Frank family had been unable to enter the U.S. as refugees under President Roosevelt in 1941 or that Anne was among the nearly six million Jewish individuals who had perished in the Nazi concentration camps. ${ }^{10}$

\footnotetext{
${ }^{1}$ Dominick LaCapra, Writing History, Writing Trauma (Baltimore: Johns Hopkins University Press, 2001), 14.

${ }^{2}$ Ibid., 14; Steven Spielberg, dir., Schindler's List (Universal Pictures, 1993), 195 mins.

${ }^{3}$ Spielberg, Schindler's List, 02:25:15.

${ }^{4}$ For more on the role of Anne Frank's father, Otto, in the publication and shaping of the story, see Cynthia Ozick, "The Misuse of Anne Frank's Diary," The New Yorker, September 29, 1997, accessed September 6, 2018, https:// www.newyorker.com/magazine/1997/10/06/who-owns-anne-frank. As Ozick writes, Otto Frank, who survived the Holocaust, "confessed that his daughter's diary made him feel he 'did not know' her, but that did not stop him from altering the diary before publication and approving a play that falsified it further." See also, Carol Ann Lee, The Hidden Life of Otto Frank, reprint edition. (New York: Harper Perennial, 2003).

${ }^{5}$ George Stevens, dir., Penny Serenade (Columbia Pictures, 1941), 104 mins.

${ }^{6}$ George Stevens, dir., The More the Merrier (Columbia Pictures, 1943), 120 mins.

${ }^{7}$ George Stevens, dir., Giant (Warner Brothers, 1956), 201 mins.

${ }^{8}$ For more on the role of George Stevens (and several other major directors, including John Ford, William Wyler, Frank Capra, and John Huston) and the relationship between Hollywood and the U.S. government in producing war propaganda, see Mark Harris, Five Came Back: A Story of Hollywood and the Second World War (New York: Penguin, 2014).

${ }^{9}$ In 1991, eleven years after Otto Frank's death, the "restored" diary was published, including references he had expunged, such as descriptions of masturbation, Yom Kippur, Anne's anger toward her mother ("the most rotten person in the world"), etc. See Ozick, The Misuse of Anne Frank's Diary; see also Alvin H. Rosenfeld, The End of the Holocaust (Bloomington: Indiana University Press, 2011), 105-106.

${ }^{10}$ Rebecca Erbelding and Gertjan Broek, German Bombs and US Bureaucrats: How Escape Lines from Europe Were Cut Off (Anne Frank House \& United States Holocaust Memorial Museum, July 2018), 4, accessed July 15, 2020, https://www. annefrank.org/es/downloads/filer public/94/3e/943ed001-ba04-4e2a-9360-e642d0d82006/ushmm afh july2018.pdf. For more on the circumstances surrounding Otto Frank's foiled attempts to take refuge in the United States, including
} 
But the edits were not just a matter of censoring material to avoid cultural taboos. The writers and directors insisted on ending the film on an uplifting note, concluding with Frank's reflection that "people were really good at heart" - much as Itzhak Stern's character would insist, years later, in Schindler's List, that the list of names was "absolute good."11 Consequently, these American adaptations rendered Frank a one-dimensional, cardboard cut-out onto which audiences could project their own ideas of girlhood innocence. Hollywood's strategy of harmonizing a narrative such as Frank's story left an indelible imprint on subsequent films about historic genocides, including The Killing Fields ${ }^{12}$ and Hotel Rwanda. ${ }^{13}$ While these films may raise popular awareness about historical genocides, they do so at a price. By bowdlerizing the past and implicitly promising a better future, they can blind us to atrocities taking place in the present.

Drawing from literary and cultural studies, I examine the narrative alchemy through which a historical trauma ending in a Dutch teenager's death was spun into a U.S. morality play. Tracing the metamorphosis of Frank's own diary from play to film adaptation, this article builds on existing scholarship to focus on how, in the wake of what has become known as the Holocaust, Hollywood began to construct popular and simplified understandings of complex genocidal crimes - all in the name of celebrating a globalized humanity. ${ }^{14}$ In the first part of the article, I take a longer view of these adaptations by situating U.S. interpretations of Frank's diary within a lineage of other Hollywood versions of historical genocide. I argue that in making Anne Frank's story morally simplistic and ultimately uplifting for U.S. audiences - in other words, shaping it into a "harmonizing narrative" - these Broadway and Hollywood adaptations prioritized rose-colored narratology that would influence future mainstream cinematic representations in dangerous ways. The second part of this article considers cinematic alternatives from outside of Hollywood (such as Canada, Rwanda, and Spain) that challenge these harmonizing narratives by enlisting a mise en abyme structure - the nesting of stories within stories - that ultimately suggest the full representation of genocide is impossible. By making false promises of harmony, Hollywood's interpretation of Frank's story has, in turn, limited our understanding of subsequent genocides. On the other hand, alternative modes of cinematic storytelling-most notably, ones that fracture a coherent narrative-compel the audience to grapple with questions of spectatorship, agency, and above all, the problems of representation.

\section{Entertainment and Evidence}

George Stevens, the American director of the 1959 Hollywood film The Diary of Anne Frank, 15 was no stranger to the horror of the Nazi concentration camps. As a major in the U.S. Army's Signal Corps, Stevens had personally documented the aftermath of Dachau, which he had likened to "wandering around in one of Dante's infernal visions."16 The footage gathered led to two documentary films, which were entitled The Nazi Plan ${ }^{17}$ and Nazi Concentration Camps. ${ }^{18}$ In the 1945 Nuremberg Trials, during which a tribunal tried twenty-four of the political leaders of the Third Reich, prosecutors screened Stevens' documentary evidence "on the grounds that it was necessary

\footnotetext{
barriers such as quotas on refugees and U.S. government concerns about spy networks, see Erbelding and Broek, German Bombs and US Bureaucrats. 
in order to offer proof of the unprecedented horror of the crimes."19 After French, British, and American newspaper reports of German atrocities during World War I had proved to be "the prevarications of propagandists," jurists such as American Robert H. Jackson, chief counsel for the Allied prosecution, felt compelled, as he said in a letter to President Truman in June 1945, to "establish incredible events by incredible evidence." ${ }^{20}$ Nuremberg hence marked the first time that documentary film had been used in court as evidence of mass atrocities. ${ }^{21}$ According to film historian Mark Harris, directly after the war, Stevens filed away his wartime footage, ranging from locations including North Africa to D-Day to Dachau, storing it in a facility in North Hollywood.

The footage had never been shown publicly. He carefully labelled each canister with titles like 'Eyewitness at Dachau' or simply 'Atrocity.' He retrieved the reels only once, in 1959, when he was preparing to direct The Diary of Anne Frank. Alone in a screening room, he started to watch what he had shot, but turned the projector off after the first minute, returned the canisters to North Hollywood, and locked them away once again... It remained in storage until his death. ${ }^{22}$

Indeed, the commercial needs of late 1950s Hollywood proved different than those of the evidentiary ones of the international courts. But perhaps Stevens, too, wishing to avoid revisiting the black and white footage of Dante's visions, chose to see a young Jewish girl's life-and death-en rose, or rose-colored.

Directly after the war, Stevens, a longtime Hollywood director known for his pre-war musicals and comedies such as Woman of the Year ${ }^{23}$ and Swing Time, ${ }^{24}$ returned to the movie sets of Los Angeles. He would go on to direct what was known as his "American Trilogy" - the melodrama A Place in the Sun ${ }^{25}$ and the iconic Westerns Shane ${ }^{26}$ and Giant. ${ }^{27}$ In 1959, he returned to the topic of the Holocaust with the film version of The Diary of Anne Frank, in which he originally sought to cast Audrey Hepburn in the title role. ${ }^{28}$ After screening an early version of the film in San Francisco, Stevens eliminated the final scene, which featured a shot of Anne in a concentration camp, "swaying in a numb miasmic fog;" 29 the director felt it was "too tough in audience impact and against 20th[Century] Fox's desire to have the film considered 'hopeful' despite all." ${ }^{30}$ Instead, the final cut of the film concludes with Anne's father, Otto Frank (Joseph Schildkraut), studying a tattered page that included what would become the most famous line of his daughter's diary - "[i]n spite of

${ }^{19}$ Kristi M. Wilson and Tomás F. Crowder-Taraborrelli, eds., Film and Genocide (Madison: University of Wisconsin Press, 2012), 8.

${ }^{20}$ Quoted in Lawrence Douglas, "Film as Witness: Screening Nazi Concentration Camps before the Nuremberg Trials," The Yale Law Journal 105, no. 2 (November 1995), 451-452. In his opening statement, Jackson discussed the role that the documentary would play-" [w] we will show you the concentration camp in motion pictures, just as the Allied armies found them when they arrived...Our proof will be disgusting and you will say I have robbed you of your sleep...I am one who received during this war the most atrocity tales with suspicion and skepticism. But the proof here will be so overwhelming that I venture to predict that not one word I have spoken will be denied." Quoted in Douglas, Film as Witness, 450.

${ }^{21}$ Douglas writes: "[t]his use of film in a juridical setting was unprecedented. Crime scene photography was well established in Anglo-American courts; and while the turn to filmic proof was perhaps a logical extension of available technology, it nevertheless marked a wholly new method of documenting criminality. Though motion pictures had been submitted as trial evidence as early as 1915, prior to Nuremberg, one can find no records of any court using graphic film of atrocities as proof of criminal wrongdoing." Quoted in ibid., 450-451.

${ }^{22}$ Harris, Five Came Back, 444.

${ }^{23}$ George Stevens, dir., Woman of the Year (Metro-Goldwyn-Mayer, 1942), 114 mins.

${ }^{24}$ George Stevens, dir., Swing Time (RKO Radio Pictures, 1936), 103 mins.

${ }^{25}$ George Stevens, dir., A Place in the Sun (Paramount Pictures, 1951), 122 mins.

${ }^{26}$ George Stevens, dir., Shane (Paramount Pictures, 1953), 118 mins.

27 Stevens, Giant.

${ }^{28}$ Marilyn Ann Moss, Giant: George Stevens: A Life on Film (Madison: University of Wisconsin Press, 2004), 247.

${ }^{29}$ Quoted in Tim Cole, Selling the Holocaust: From Auschwitz to Schindler; How History Is Bought, Packaged, and Sold, 1 st ed. (New York: Routledge, 2000), 34.

${ }^{30}$ Ibid. 
everything, I still believe that people are really good at heart." 31 His following line, "She puts me to shame," implies that to react with anything other than the optimism found in that line in the diary is, to use Otto's word, "shameful."32

This uplifting ending complemented Stevens' stubborn insistence on Frank's symbolism of universal goodness and hope. In an on-set interview in 1959, he informed a reporter, "our emphasis is on the wonderful little girl who was Anne...She had an inner light, a warmth that not even the terrible experience of confinement could douse." 33 The same journalist wryly remarked of the Broadway and cinematic adaptation: "It should have been a grim play, but it was not. And the movie will not dwell on the depressing aspects of the story either." ${ }^{34}$ As Holocaust scholar Alvin Rosenfeld writes of the diary's adaptation, "by emphasizing the tender and more ennobling aspects of youthful sentiment in the book and deemphasizing its darker dimensions, it became possible to project an image of Anne Frank that softened somewhat the revulsion and horror that otherwise might have directed readers' responses to the diary." ${ }^{35}$ In the world of these U.S. screenwriters and directors, optimism trounced pessimism. As evidenced by the critical acclaim, many Americans welcomed this sanitized version of history: both productions received accolades, including the play's 1956 Pulitzer Prize and the film's multiple Academy Award nominations in $1960 .^{36}$

Stevens, however, was not the first Hollywood director to portray aspects of the Holocaust through feature film. ${ }^{37}$ Fred Zinnemann's The Search, ${ }^{38}$ which tells the story of Karel, a young Czech boy (Ivan Jandl) displaced from a concentration camp, earned critics' praise and seemed to embody the postwar zeitgeist with its British Academy of Film and Television Arts (BAFTA) award for "best embodying the principles of the United Nations Charter." ${ }^{39}$ As historian Lawrence Baron writes, the plot of the film, shot on location in the remnants of bombed German cities, is "an exercise in unabashed sentimentality" that results in a "contrived happy ending" - a reunion between Karel and his mother Hanna (Jarmila Novotná). ${ }^{40}$ In 1953, Kirk Douglas starred as Hans Muller, a concentration camp survivor who arrives in Israel, in Edward Dmytryk's melodrama The Juggler, ${ }^{41}$ a film adapted from the novel of the same name. Three years later, Max Nosseck's Singing in the

\footnotetext{
${ }^{31}$ George Stevens, dir., The Diary of Anne Frank, 02:53:38-02:53:45.

${ }^{32}$ Ibid., 02:53:45-02:53:48.

${ }^{33}$ Quoted in Paul Cronin, ed., George Stevens: Interviews (Jackson: University of Mississippi Press, 2004), 16.

${ }^{34}$ Quoted in Ibid., 16.

${ }^{35}$ Rosenfeld, The End of the Holocaust, 103-104.

${ }^{36}$ The film's Academy Awards included Best Actress in a Supporting Role (Shelley Winters) and Best Cinematography, Black-and-White (William C. Mellor). It was also nominated for Best Picture (George Stevens) and Best Actor in a Supporting Role (Ed Wynn). See also Judith Doneson, "The American History of Anne Frank's Diary," Holocaust and Genocide Studies 2, no. 1 (1987), 154.

${ }^{37}$ These films were not the first to portray historical genocide on the Hollywood screen, as evident in Ravished Armenia, directed by Oscar Apfel, produced by William Selig (First National Pictures, 1919), a 1919 silent film based on the memoir of Aurora Mardiganian, a survivor of what would become known as the Armenian genocide. As Donna-Lee Frieze has pointed out, Mardiganian has retrospectively been called the "Anne Frank" of the Armenian genocide. Donna-Lee Frieze, "Arshaluys Mardigian/Aurora Mardiganian: Absorption, Stardom, Exploitation, and Empowerment," in Women and Genocide: Survivors, Victims, Perpetrators, ed. Elissa Bemporad and Joyce W. Warren. (Bloomington: Indiana University Press, 2018), 59; for more on the adaptation, screenplay, and history of Apfel's silent film, see Aurora Mardiganian and Henry Leyford Gates, Ravished Armenia and the Story of Aurora Mardiganian, ed. Anthony Slide (Jackson: University of Mississippi Press, 2014).

${ }^{38}$ Fred Zinnemann, dir., The Search (Loew's, Inc., 1948), 105 mins.

${ }^{39}$ Bosley Crowther, "Straight to the Heart: 'The Search' a Great Film Drama With Vital Appeal," New York Times, April 4, 1948, 1. Crowther's review in The New York Times assured future spectators that emotional uplift of the film would outweigh its depressing subject matter: "[r]egarding that other anxiety as to possible distress in this film, let us add this further assurance the compensations far outweigh the pain. Among these compensations are the insight this picture gives into the nature of decent people who have compassion and time for sufferers." Crowther, Straight to the Heart, 1.

${ }^{40}$ Lawrence Baron, Projecting the Holocaust into the Present: The Changing Focus of Contemporary Holocaust Cinema (Lanham: Rowman \& Littlefield Publishers, 2005), 30.

${ }^{41}$ Edward Dmytryk, dir., The Juggler (Columbia Pictures, 1953), 86 mins.
} 
Dark, $^{42}$ the story of a cantor's son and Holocaust survivor (Moyshe Oysher) suffering from amnesia who immigrates to the United States, was released. ${ }^{43}$

Still, treatment of the Holocaust was relatively rare in the postwar years, and American viewers were shielded from many of the harsher realities of the historical atrocity. Scholars such as Eric Goldman have shown that in the wake of the war, "influential members of the Los Angeles Jewish community" ${ }^{44}$ were reticent to draw attention to the plight of Jewish individuals on screen, even calling a meeting at Warner Brothers to discourage the making of the film Gentleman's Agreement. They feared that "by drawing attention to anti-Semitism in a film, anti-Semitic feelings might be enhanced." ${ }^{45}$ Historian Peter Novick attributes this relative absence of representation of the Holocaust during the 1950s to several reasons, including a historicization of the Holocaust as "a terrible feature of the period that had ended with the defeat of Nazi Germany,"46 an aversion to what seemed to many like an "unhealthy voyeurism" of atrocities, and the advent of the Cold War, which transformed Germans "from implacable foes to indispensable allies." 47 For example, in 1959, when Judgment at Nuremberg first screened as a teleplay on Playhouse $90^{48}$ (prior to Stanley Kramer's Hollywood film version in $1961^{49}$ ), all references to the gas chambers were cut due to objections from the American Gas Association, one of the show's sponsors. ${ }^{50}$ Indeed, compared to the films that preceded it - which focused on postwar issues such as displaced persons, courtroom prosecution of war criminals, and the psychological aftermath of surviving the concentration camps-Stevens' cinematic adaptation of Frank's diary shifted the focus of cinematic storytelling by "plac[ing] the dangers of Jewish existence in wartime Europe at the center of its narrative." 51 But even after documenting the aftermath of the concentration camps on film in 1945, Stevens chose to tell the story of the young Frank, even in its dangerous moments of Nazis pounding at the annex doors, through a rose-colored lens. The film footage of Dachau remained locked in North Hollywood, and the director had decided to never again use the key.

\section{Americanizing Anne Frank}

As early as the book's U.S. publication in 1952, American readers and critics had already begun to metonymize Frank as a symbol of both hope and suffering. In the book's introduction, Eleanor Roosevelt framed the story as one to which any American reader could relate. "These are the thoughts and expression of a young girl living under extraordinary conditions, and for this reason her diary tells us much about ourselves and our own children. And for this reason, too, I felt how close we all are to Anne's experience." 52 Here, Roosevelt enlisted the plural pronoun "we," insisting on the universality of the teen diarist's experience.

Certain Jewish critics, however, focused on the particularity of Frank's religious identity. In June of that same year, The New York Times Book Review published a piece by novelist Meyer Levin,

${ }^{42}$ Max Nosseck, dir., Singing in the Dark directed by (A.N.O. Productions, 1956), 104 mins.

${ }^{43}$ See Jeffrey Shandler, Jews, God, and the Videotape: Religion and Media in America (New York: New York University Press, 2009), 42-43.

${ }^{44}$ Eric A. Goldman, American Jewish Story through Cinema, 1st ed. (Austin: University of Texas Press, 2013), 4.

${ }^{45} \mathrm{Ibid}$. Darryl F. Zanuck, the head of production at the studio, insisted on producing Gentleman's Agreement, the adaptation of Laura Z. Hobson's novel of the same name. As Goldman writes, Zanuck, "by his very character, was no conformist, and understood that, by virtue of not being a Jew, he could take liberties that Jews would not take." Goldman, American Jewish Story, 3. Directed by Elia Kazan, the film version of Gentleman's Agreement, which stars Gregory Peck as a non-Jewish journalist who goes undercover to expose anti-Semitism in the United States, won the Academy Award for Best Picture in 1947. See Elia Kazan, dir., Gentleman's Agreement, produced by Darryl F. Zanuck (Twentieth Century Fox, 1947), 118 min.

${ }^{46}$ Peter Novick, The Holocaust in American Life, (Boston: Houghton Mifflin, 1999), 103

${ }^{47}$ Ibid., 86.

${ }^{48}$ Playhouse 90, Los Angeles, aired on CBS from 1956-1960.

${ }^{49}$ Stanley Kramer, dir., Judgement at Nuremberg (Roxlom Films Inc., 1961), 179 minutes.

${ }^{50}$ Annette Insdorf, Indelible Shadows: Film and the Holocaust, 3rd ed. (Cambridge; New York: Cambridge University Press, 2002), 3.

${ }^{51}$ Baron, Projecting the Holocaust, 39.

${ }^{52}$ Eleanor Roosevelt, "Introduction," in Anne Frank: The Diary of a Young Girl (Garden City: Doubleday \& Company, Inc., 1952), 8. 
who suggested that her story could stand in for all of the Jewish people who had perished in the Holocaust - "[b]ecause the diary was not written in retrospect, it contains the trembling life of every moment-Anne Frank's voice becomes the voice of six million vanished Jewish souls." 53 Soon after, however, it was precisely Frank's Jewish identity that the team of U.S. playwrights sought to minimize, describing the Hanukkah ceremony as "eight days of presents" and replacing the religious hymn "Rock of Ages," with a "spirited and gay" jingle. Garson Kanin, the director of the Broadway version of the diary, claimed that any use of Hebrew would "simply alienate the audience." ${ }^{54}$ Broad way and Hollywood producers effectively shoehorned the story of the Holocaust into classic cinematic tropes, including, in the words of Annette Insdorf, "a confined theatrical setting, superfluous dialogue, star turns, classical editing (mainly with close-ups), and musical scores whose violins swell at dramatic moments." 55 Along with films such as Stanley Kramer's 1961 courtroom drama Judgment at Nuremberg, ${ }^{56}$ Stevens' production of The Diary of Anne Frank "essentially fit the bristling new material of the Holocaust into an old narrative form, thus allowing the viewer to feel complacent instead of concerned or disturbed." ${ }^{57}$ Indeed, these aesthetic cues anesthetized the historical accuracy, bowdlerized Frank's death in Bergen-Belsen, and suggested to U.S. audiences that a representation of the Holocaust could end as most Hollywood films didhappily.

As anthropologist Liisa Malkki writes, in the transnational sphere, the figure of the child often performs "ritual and affective work" that may invoke a "human community" and the "embodiment... of a basic human goodness." ${ }^{58}$ The case of Anne Frank was no exception. The edits made by American producers kept Frank safely in the cocoon of childhood, away from the murky psychological waters of adolescence or rage at the world around her, which might muddle her personification of goodness. Writer Cynthia Ozick counts the ways in which American producers altered the diary's content in the decades since its publication. "The story of Anne Frank...has been bowdlerized, distorted, transmuted, traduced, reduced; it has been infantilized, Americanized, homogenized, sentimentalized; falsified, kitschified, and, in fact, blatantly and arrogantly denied." ${ }^{59}$ Many Jewish intellectuals in the late 1950s and early 1960s shared these concerns, balking at what they perceived as the whitewashing of history for the edification of the American audiences. ${ }^{60}$ For instance, in an essay published in the Chicago-based Critic in 1960, Martin Dworkin expressed concern that because the playwrights minimized Frank's Jewish identity and emphasized her budding romance with Peter, the quintessence of the story would be lost on the American audience. "To these people, this Anne Frank may not represent the millions of Jews who were obliterated, as much as the popular image of youth's indictment of the adult world that perpetually interferes with the romantic fulfillment of adolescent dreams." ${ }^{16}$ Dworkin went on to criticize how the book's "central poignance has been subtly diluted in order to give a familiar

\footnotetext{
${ }^{53}$ Meyer Levin, "The Child Behind the Secret Door," The New York Times Book Review, June 15, 1942, accessed July 15, 2020, https://timesmachine.nytimes.com/timesmachine/1952/06/15/93375295.html?pageNumber=93. For more on Levin's relationship to the adaptations of the diary and his complicated-even litigious - relationship with Otto Frank, see Ozick, The Misuse of Anne Frank's Diary; Rosenfeld, The End of the Holocaust, 133-134; Peter Novick, The Holocaust in American Life, 103-123.

${ }^{54}$ Quoted in Ozick, The Misuse of Anne Frank's Diary.

${ }^{55}$ Insdorf, Indelible Shadows, 6.

${ }^{56}$ Kramer, Judgement at Nuremberg.

${ }^{57}$ Insdorf, Indelible Shadows, 6.

${ }^{58}$ Liisa Malkki, “Children, Humanity, and the Infantilization of Peace," in In the Name of Humanity: The Government of Threat and Care, ed. Ilana Feldman et al. (Durham: Duke University Press, 2010), 59-60. Malkki suggests that children consistently occupy five registers in the humanitarian imagination: "(1) as embodiments of basic human goodness (and symbols of world harmony); (2) as sufferers; (3) as seers of truth; (4) as ambassadors of peace; and (5) embodiments of the future." Quoted in Malkii, Children, Humanity, and the Infantilization, 59-60. For a discussion of portrayals of the Holocaust in children's literature, see Ruth Franklin, "How Should Children's Books Deal with the Holocaust?," The New Yorker, July 16, 2018, accessed July 15, 2020, https://www.newyorker.com/magazine/2018/07/23/ how-should-childrens-books-deal-with-the-holocaust.

${ }^{59}$ Ozick, The Misuse of Anne Frank's Diary.

${ }^{60}$ Rosenfeld, The End of the Holocaust, 131.

${ }^{61}$ Martin Dworkin, “The Vanishing Diary of Anne Frank,” The Critic 18, no. 4 (February 1, 1960), 76.
} 
soft-drink flavor," ${ }^{62}$ stating his concern that the majority of U.S. theatergoers or filmgoers "know little of the facts of the extermination of six million Jews by Nazis and will not be led to [such] knowledge in the theaters." ${ }^{13}$ In Harper's Magazine that same year, Austrian-Jewish psychoanalyst Bruno Bettelheim (himself a former prisoner of Buchenwald and Dachau concentration camps) resisted the logic of the American adaptations' implicit message, writing that Frank's story "found wide acclaim because...it denies implicitly that Auschwitz ever existed. If all men are good, there was never an Auschwitz." ${ }^{64}$ Indeed, in the immediate postwar years, most U.S. citizens, even those who were Jewish, were reluctant to grapple publicly with the facts of what would become known as the Holocaust until the 1970s. ${ }^{65}$

The film's final words about the goodness of peoples' hearts-one of Frank's most enshrined quotations-epitomize what seems an unshakable faith in humanity. Yet Frank was more complicated -indeed, more human - than that single line suggests. As Samantha Power observes, these U.S. productions banished Frank's lines that expressed profound doubt about the future. ${ }^{66}$ In a line penned on April 11, 1944, Frank articulated despair, writing, "[w]e are Jews in chains." ${ }^{67}$ The following month, on May 3, she described humanity's Hobbesian side, writing, "there's a destructive urge in people, the urge to rage, murder, and kill." 68 That summer, on July 15, 1944, Frank wrote, "I simply can't build up my hopes on a foundation consisting of confusion, misery, and death." ${ }^{\prime \prime 9}$ Lines such as these, threads in the diary's tapestry, remind us of the story's darker elements. As Ozick writes of the document, "its reputation for uplift is, to say it plainly, nonsensical. ${ }^{\prime \prime 0}$ We would do well to recall that in spite of U.S. producers' attempts to universalize Frank's story through such an uplifting, optimistic understanding of her life (and death), this approach was far from universal.

Zooming out from the United States, it becomes clear that national context shaped local understanding of the diary, the play, and the film. In fact, Frank's story serves as a type of Rorschach test-responses to it tell us at least as much about the sociohistorical circumstances of the audience as about the life of Frank herself. For instance, in mid-century South Africa, productions of the play staged in English and Afrikaans diverged from the American script in order to accentuate Frank's Jewish identity, thus "emphasizing the story's particularity and deflecting local connotations" of the apartheid racialized state for white audiences. ${ }^{71}$ More recently, Caribbean writers such as Michelle Cliff have written "under the sign of Anne Frank" through novels such as Aben ${ }^{72}{ }^{72}$ in which a Jamaican girl, fascinated with the Dutch diarist, embarks upon a "quest to come to terms with the Holocaust,"73 all the while grappling with the particular legacy of colonialism and racism in her own country. ${ }^{74}$ In an entry in Zlata's Diary dated March 30, 1992, the eponymous writer, a young girl living in wartime Sarajevo, indirectly aligns her own story with Frank's, confiding, "[h]ey,

${ }^{62}$ Ibid., 16

${ }^{63}$ Ibid., 77.

${ }^{64}$ Bruno Bettelheim, “The Ignored Lesson of Anne Frank," Harper's Magazine, November 1, 1960, 46.

${ }^{65}$ Samantha Power, "A Problem from Hell:" America and the Age of Genocide, reprint ed. (New York: Basic Books, 2013), 7273. Power describes the climate of reticence in "the immediate postwar period ... [in which] the singular genocide so well-known today was barely discussed. American Jews who would later become a potent force in promoting Holocaust commemoration and education were reticent, eager to assimilate, leery of fueling further anti-Semitism, and determined not to be depicted as victims. Other Americans were uncomfortable with the topic of extermination." Quoted in Power, A Problem from Hell, 72.

${ }^{66}$ Ibid., 73.

${ }^{67}$ Anne Frank, The Diary of a Young Girl, ed. Otto H. Frank, trans. Susan Massotty (New York: Anchor Books, 1996), 262.

${ }^{68}$ Ibid., 281.

${ }^{69}$ Ibid., 333.

${ }^{70}$ Ozick, The Misuse of Anne Frank's Diary.

${ }^{71}$ Shirli Gilbert, "Anne Frank in South Africa: Remembering the Holocaust During and After Apartheid," Holocaust and Genocide Studies 26, no. 3 (December 23, 2012), 368.

${ }^{72}$ Michelle Cliff, Abeng, First Plume Printing ed. (New York: Plume, [1984] 1995).

${ }^{73}$ Sarah Phillips Casteel, "Writing Under the Sign of Anne Frank: Creolized Holocaust Memory in Michelle Cliff and Caryl Phillips," Modern Fiction Studies 60, no. 4 (December 29, 2014), 798.

${ }^{74}$ Ibid. 
Diary! You know what I think? Since Anne Frank called her diary Kitty, maybe I could give you a name, too," before choosing the name of Mimmy. ${ }^{75}$ Thus, in spite of U.S. producers' attempts to universalize Frank's diary, uses of her story - whether as pedagogical tools, literary adaptations, or generic inspiration - were (and still are) far from homogenous. ${ }^{76}$ Still, the diary's quintessence unites these disparate and global interpretations of the young girl's diary.

Frank's legacy in Hollywood extends well beyond the 1959 film. As we will see, harmonizing narratives such as Stevens' production were harmful not only because of their bowdlerization of history but also their foreclosure of our ability to encounter representations of genocidal atrocity when it happens in the future.

\section{Rose-Colored Hollywood}

The paradigm of harmonizing narratives surrounding U.S. adaptations of Frank's story has since left its trace on several more recent Hollywood-produced films about genocide. ${ }^{77}$ Examples include acclaimed films such as Terry George's Hotel Rwanda ${ }^{78}$ and Roland Joffé's The Killing Fields. ${ }^{79}$ Hotel $R w a n d a^{80}$ features a linear, teleological plot with very little historical context for its intended audience before insisting on an uplifting ending, much like its cinematic kin, Schindler's List. ${ }^{81}$ As one critic explained, Hotel Rwanda's absence of historical background for the Rwandan genocide "makes the violence meaningless and reproduces the 'Dark Continent' narrative trope of Africa, where violence is portrayed as a way of life." ${ }^{\prime 2}$ In fact, much of the film's paratextual publicity grafted the story of Oskar Schindler, the German Nazi with a heart of gold, onto the story of how Kigali's Belgian-owned Hôtel Mille Collines became a haven for Tutsis and moderate Hutus in the midst of the 1994 genocide. Publicity for the film crowned its hero, Hutu hotel manager Paul Rusesabagina (Don Cheadle), as "Rwanda's Schindler" - in spite of his controversial legacy in Rwanda and the contestation of his heroism by Hôtel Mille Collines survivors, an internationalist journalist, and United Nations troops who were in Kigali at the time of the genocide..$^{83}$ The film leans on a plot

${ }^{75}$ Zlata Filipovic, Zlata's Diary: A Child's Life in Wartime Sarajevo, trans. Christina Pribichevich-Zorie. (New York: Penguin Books, 2006), 27. Indeed, as Katherine Wilson points out in her study of the global reception of Anne Frank's story, localized cultural context often determines the nature of its reception - "[i]f we look at the Diary's circulation, what we actually see are (at least) three separate modes of transnational reception: first, as translation affecting the way non-Western communities represent their experiences of genocide; second, as a text read by protagonists of novels; and third, as an authorizing force resulting in the rise of multiple foreign 'Anne Franks'." Quoted in Katherine Wilson, "Anne Frank Abroad: The Emergence of World Atrocity Literature," World Literature Today 87, no. 3 (June 2013 ), 32.

${ }^{76}$ See also Robert Sackett, “Memory by Way of Anne Frank: Enlightenment and Denial Among West Germans, Circa 1960," Holocaust and Genocide Studies 16, no. 2 (September 1, 2020), 243-265; on reception of the text in 1960s Germany, see Youssef Ben Lamia Zayzafoon, "Anne Frank Goes East: The Algerian Civil War and the Nausea of Postoloniality in Wacing Laredj's 'Balconies of the North Sea'," College Literature 37, no. 1 (2010), 61-80; on the connection between Anne Frank's legacy and the Algerian Civil War, see Angela Coutts, "Remembering Anne Frank in Japan: Akazome Akiko's Otome No Mikkoku/The Maiden's Betrayal," Contemporary Women's Writing 8, no. 1 (March 2014), 71-88; also on the literary use of the diary in Akazome Akiko's 2010 novel Otome no Mikkoku (The Maiden's Betrayal) which also grapples with questions of war and memory in Japan.

${ }^{77}$ Spielberg's film is also an adaptation. It is based on Thomas Keneally's book, Schindler's Ark (London: Hodder and Stoughton, 1982), which was released in the United States as Schindler's List.

${ }^{78}$ George, Hotel Rwanda.

${ }^{79}$ Joffé, The Killing Fields.

${ }^{80}$ George, Hotel Rwanda.

${ }^{81}$ In contrast to Hotel Rwanda, Haitian director Raoul Peck's 2005 Sometimes in April, a feature film also about the Rwandan genocide, provides at least some overview of the colonial history in the century preceding the genocide, alluding to the Hamitic hypothesis, a racialized myth that privileged the Tutsi because of their perceived genetic proximity to Europeans, and its poisonous legacy. See Raoul Peck, dir., Sometimes in April, (HBO Films, 2005), 140 min.

${ }^{82}$ Okaka Opio Dokotum, "Re-Membering the Tutsi Genocide in Hotel Rwanda (2004): Implications for Peace and Reconciliation," African Conflict \& Peacebuilding Review 3, no. 2 (Fall 2013), 130, 134.

${ }^{83}$ For more on Rusesabagina's contested legacy in Rwanda, see Dokotum, Re-Membering the Tutsi Genocide, 132-144. As Zylberman and Sánchez-Biosca noted, by describing Hotel Rwanda as "the black version" of Schindler's List, such reflexive comparisons between Schindler and Rusesabagina "thus marginalize any possible discussion regarding the historical figure of the main character." Quoted in Lior Zylberman and Vicente Sánchez-Bosca, "Reflections on the Significance of Images in Genocide Studies: Some Methodological Considerations," Genocide Studies and Prevention 12, no. 2 (2018), 6. For more on the parallels between Schindler's List and Hotel Rwanda, see Madelaine Hron, "Genres of 
that concludes with an uplifting scene of an improbable family reunion and survival in a refugee camp - with key details that differ from the facts in Rusesabagina's own memoir, whose accuracy itself has been questioned. ${ }^{84}$

Thematically, Hotel Rwanda's ending of reunion, survival, and the triumph of "good over evil" synchronizes with the final scene of The Killing Fields, a film made twenty years prior about the Cambodian genocide. Here, American photojournalist Sydney Schanberg (Sam Waterston) reunites in a Thai refugee camp with the man he calls his "best friend," Dith Pran (Haing S. Ngor), who has lived through the Khmer Rouge genocide. Schanberg apologizes for leaving his friend behind during the 1975 American evacuation from Phnom Penh, having fled what he earlier called "the sad little country." 85 Pran in turn absolves any sense of guilt - "[n]othing to forgive, Sydney," he says-before the two men embrace. ${ }^{86}$ Because the two characters metonymically represent their respective countries, the film's ending wriggles away from any serious self-examination of what Power calls "American reticence in face of the Cambodian horrors" that took place between 1975 and $1979 .{ }^{87}$ In the aftermath of the genocide, hope has the last word.

In spite of harmonizing narratives, some of these Hollywood films include fleeting moments that self-reflexively question the role of the camera and storytelling in the midst of atrocity. Occasionally, these scenes include snippets of what is known as mise en abyme. In this narrative technique-literally "placed in the abyss" - stories are embedded within stories. ${ }^{88}$ For instance, in one scene of Hotel Rwanda, Rusesabagina watches documentary footage of genocidal carnage, taken by Jack Daglish (Joaquin Phoenix), an American photojournalist, from the relative safety of the hotel. The hotel manager expresses his hope that visual evidence of collective violence in the streets of Kigali will incite Western action. "How can they not intervene when they witness such atrocities?," he asks. ${ }^{89}$ Puncturing Rusesabagina's optimism, the journalist responds, "I think that if people see this footage they'll say, 'Oh my God that's horrible,' and then go on eating their dinners." 90 The film makes a subtle suggestion here: will the audience of Hotel Rwanda respond in kind to this story of the Rwandan genocide? This scene opens up critical space that interrogates the nature of documentation, evidence, spectatorship, and atrocity. Although only for a brief moment, the mise en abyme fractures the arc of the harmonizing narrative.

'Yet Another Genocide': Cinematic Representations of Rwanda," in Film and Genocide, ed. Kristi M. Wilson and Tomás F. Crowder-Taraborrelli (Madison: University of Wisconsin Press, 2012), 140.

${ }^{84}$ In the film, the family is escorted to the refugee camp by United Nations peacekeepers and finds their young relatives in relatively good, well-kept conditions. In Rusesabagina's autobiography, on the other hand, the family is escorted by the Rwandan Patriot Front to the Kabuga refugee camp and finds Rusesabagina's brother-in-law's children, Anaise and Izere, "covered in dirt...starving, and barely alive." Paul Rusesabagina and Tom Zoellner, An Ordinary Man: An Autobiography (New York: Viking Penguin, 2006), 166. For more on the collaboration between director Terry George and Rusesabagina as well as the contestations against the hotel manager from Hôtel Mille Collines survivors, troops from UNAMIR (United Nations Assistance Mission for Rwanda), and an international journalist, see Dokotom, ReMembering the Tutsi Genocide.

${ }^{85}$ Joffé, The Killing Fields, 00:08:07-00:08:11.

${ }^{86}$ Ibid., 02:15:41-02:15:44.

${ }^{87}$ Power, A Problem from Hell, 91. For more on the context of the "U.S. policy of silence" in Cambodia see Power, A Problem from Hell, 128, even in the face of analogies to the Holocaust, see Power, A Problem from Hell, 87-154 .

${ }^{88}$ Oxford English Dictionary Online (Oxford University Press), s.v., "mise en abyme," accessed May 16, 2018, http://www. oed.com/view/Entry/245796. In 1989, Lucien Dällenbach revisited and revised Gide's concept in The Mirror and the Text. Unlike Gide, who never actually spelled out the meaning of mise en abyme, preferring to offer only examples of it, Dällenbach helpfully provided his readers with a working definition: "a 'mise en abyme' is any aspect enclosed within a work that shows a similarly within the work that contains it." Lucien Dällenbach, The Mirror in the Text, trans. Jeremy Whitely and Emma Hughes (Chicago: University of Chicago Press, 1989), 8.

${ }^{89}$ George, Hotel Rwanda, 00:43:50-00:43:53.

${ }_{90}$ Ibid., 00:43:54-00:44:04. The Killing Fields also includes a subplot in which U.S. photojournalist Al Rockoff (John Malkovich) tries to forge a British passport for Pran's escape by taking his photo, a series of scenes which also demonstrate the power (or, conversely, the powerlessness) of the camera in the face of mass atrocity (Joffé, The Killing Fields, 01:08:30-01:19:01). For more on the Western coverage (or lack thereof) of the Rwandan genocide, see Noam Schimmel, "An Invisible Genocide: How the Western Media Failed to Report the 1994 Rwandan Genocide of the Tutsi and Why," The International Journal of Human Rights 15, no. 7 (2010), 1125-1135, accessed July 15, 2020, https://doi.org/1 $\underline{0.1080 / 13642987.2010 .499728 .}$. 
Yet, for its fleeting moments of meta-narration-its half-hearted interrogation of American spectators' apathy regarding international atrocities - the film leans on a teleological plot with a conclusion that is regretful yet ultimately uplifting. On a similar note, in the final scene of The Killing Fields, John Lennon's sad yet hopeful song "Imagine" plays in the background. ${ }^{91}$ An intertitle informs the viewer that "Dith Pran returned, with Sydney Schanberg, to America to be reunited with his family." 92 The narrative closes with a note of harmony, a sense of hope-the Western journalist returns home weary, but also wiser. ${ }^{93}$ In both films, the loose ends are tied up.

As several critics have noted, these predominant narrative tropes and patterns in Hollywood films about Rwanda, Cambodia, and the Holocaust constitute their own genre-what might be called genocide cinema. In their introduction to the critical anthology Film and Genocide, Kristi M. Wilson and Tomás F. Crowder-Taraborrelli observed that most genocide films "seem to straddle a very fine line between depicting the lack of power to stop these kinds of events and small glimmers of hope (in most cases characterized by the heroic behavior of a small number of individuals)." ${ }^{\prime 94}$ These films adapt, blending into different subgenres, and, as Lior Zylberman and Vicente SánchezBiosca write, "melodrama, the different subgenres of drama, thrillers, art films, TV series, or even Hollywood blockbusters managed to crystallize an iconography and spectacular narrative form." ${ }^{\prime 95}$ More recent examples include The Promise, ${ }^{96}$ a romance set against the backdrop of the Armenian genocide (also directed by Terry George of Hotel Rwanda), and Angelina Jolie's First They Killed My Father, ${ }^{97}$ a drama based on Loung Ung's memoir of the Cambodian genocide. ${ }^{98}$ Such optimism invests stock in the promise of never again, a mantra that aims to ward off future acts of collective violence, which, in the world beyond Hollywood, rings hollow time after time. These patterns, so finely etched into the genre of genocide cinema, make the mise en abyme structure of a film such as Ararat, ${ }^{99}$ which focuses on the Armenian genocide, all the more jarring. By refusing to harmonize the narrative of a historical genocide, it offers an alternative mode of storytelling.

\section{Embracing Dissonance: Ararat}

Directed by Atom Egoyan, Ararat is a disorienting and dizzying film. A film about a film, Ararat depicts the attempt of Armenian-Canadian director Edward Saroyan (Charles Aznavour) to cinematize the Armenian genocide based on the 1917 memoir of missionary Clarence Ussher, entitled An American Physician in Turkey: A Narrative of Adventures in Peace and War. While directing his film (also entitled Ararat), Saroyan must also grapple with the opposing political convictions of his lead Turkish-Canadian actor (Elias Koteas) who plays the role of Jevdet Bey, a Turkish government official who oversaw the massacre of Armenians during the Siege of Van in 1915, and denies off-screen that the Armenian genocide ever took place. Throughout, Egoyan consistently enlists the narrative technique of mise en abyme that was so fleetingly featured in Hotel Rwanda. Characters argue about the ethics of the screenplay, compare the Armenian genocide to the Holocaust, and even debate whether the massacre at Van ever occurred. By enlisting the mise en

\footnotetext{
${ }^{91}$ Joffé, The Killing Fields, 02:14:31-02:17:02.

${ }^{92}$ Ibid., 02:16:24.

${ }^{93}$ In Michael Ondaatje's novel Anil's Ghost, Gamini, a citizen of Sri Lanka, reflects on this dynamic of the Western hero in U.S. cinema: "American movies, English books - remember how they all end? Gamini asked that night. 'The American or the Englishman gets on a plane and leaves. That's it. The camera leaves with him. He looks out the window at Mombasa or Vietnam or Jakarta, someplace now he can look at through the clouds. The tired hero. A couple of words to the girl beside him. He's going home. So the war, to all purposes, is over. That's enough reality for the West. It's probably the history of the last two hundred years of Western political writing. Go home. Write a book. Hit the circuit." Quoted in Michael Ondaatje, Anil's Ghost (New York: Knopf, 2000), 286.

${ }^{94}$ Wilson and Crowder-Taraborrelli, Film and Genocide, 5.

${ }^{95}$ Zylberman and Sánchez-Biosca, Reflections on the Significance of Images, 12.

${ }^{96}$ Terry George, dir., The Promise (Open Road Film, 2016), 135 mins.

${ }^{97}$ Angelina Jolie, dir., First They Killed My Father, (Netflix, 2017), 136 mins.

${ }^{98}$ For a consideration of the parallels between the Hollywood depiction of the Armenian genocide in The Promise and Ravished Armenia, see Michelle Tusan, "Promises, Promises: The Strange History of Film and the Armenian Genocide," Los Angeles Review of Books, May 25, 2017, accessed September 16, 2019, https://lareviewofbooks.org/article/promisespromises-strange-history-film-armenian-genocide/.

${ }^{99}$ Atom Egoyan, dir., Ararat (Miramax, 2002), 115 minutes.
} 
abyme as a structural scaffold, Ararat exposes the ethical quandaries, political struggles, and artistic riddles of attempting to narrate a story about the historical trauma of genocide.

Ussher's memoir features an account of the 1915 Siege of Van, beginning in the spring of that year, when Jevdet Bey, the Turkish governor of Van, commandeered approximately 4,000 Armenian soldiers, allegedly for work battalions. Bey then refused the Armenians' offer-a tenth of their number as hostages and a fee to exempt the rest-before massacring 55,000 Armenians by Ussher's estimate. ${ }^{100}$ Ussher recounts a conversation in which Bey commands the Turkish forces to go to the town of Shadakh and "wipe out its people" before "savagely" telling the American, "II won't leave one, not one so high,' holding his hand below the height of his knee." ${ }^{101}$ The memoir, which includes maps, photographs, and illustrations of the bombarded buildings, vividly describes the mass slaughter led by Bey's Turkish forces, known as the Kasab Taburu, or the Butcher Regiment.

They were mounted, armed with daggers, automatic pistols, and modern repeating rifles. When they saw a mother nursing her babe they shot through the babe and the mother's breast and arm. They would gallop into a crowd of fleeing women and children, draw their daggers, and rip the unfortunate creatures. I forbear to describe the wounds brought to me to repair. ${ }^{102}$

Here, Ussher catalogues some - but not all - of the atrocities committed by Bey's forces. In refusing to describe the wounds he tended, the physician intimates a horror too great to record. In spite of his refusal to document the full extent of the carnage, Ussher's memoir is considered one of the most detailed eyewitness accounts of the genocide, and it explicitly accuses the Turkish government of planning to exterminate the Armenian population. ${ }^{103}$

Egoyan's Ararat dramatizes this failure of global witnessing through the staging of the filming of a scene on the set of Saroyan's Ararat. In this scene, one of the consultants for Saroyan's film, Ani (Arsinée Khanjian), an Armenian-Canadian art historian who specializes in the paintings of Armenian-American artist Arshile Gorky, is incredulous. ${ }^{104}$ Ani feels that the film's director has taken too many artistic liberties, such as making the mountain of Ararat visible from Van, which would have been, as she has told Saroyan, "not true."105 Later in the film, an enraged Ani barges through the set, where the actor Martin (Bruce Greenwood) playing Clarence Ussher is tending to a maimed child in the fog of apocalyptic violence. In this moment of crossing the threshold of the set, Ani literally breaks the frame of the narrative; she catalyzes a catastrophic collision of past and present, fiction and non-fiction. Angered by this interruption, the actor Martin, speaking as the character of Ussher, from the vantage of Van in 1915, explodes at twenty-first-century Ani.

What is this? God damn it! We're surrounded by Turks. We've run out of supplies, most of us will die. The crowd needs a miracle; this child is bleeding to death. If I can save his life, it may give us the spirit to continue. This is his brother... his pregnant sister was raped in front of his eyes, before her stomach was slashed open, to stab her unborn child. His father's eyes were gouged out of his head and stuffed into his mouth. And his mother's breasts were ripped off. She was left to bleed to death. Who the fuck are you? ${ }^{106}$

\footnotetext{
${ }^{100}$ Peter Balakian, The Burning Tigris: The Armenian Genocide and America's Response (New York: Harper Collins, 2003), 202207.

${ }^{101}$ Clarence Douglas Ussher and Grace Highley Knapp, An American Physician in Turkey: A Narrative of Adventures in Peace and War (Boston: Houghton Mifflin, 1917), 237-238.

${ }^{102}$ Ibid., 238

${ }^{103}$ Balakian, The Burning Tigris, 201.

${ }^{104}$ Egoyan, Ararat, 00:32:40, beginning of the scene. Gorky fled from Van and eventually settled in the United States, becoming known for his influence on Abstract Impressionism and his paintings such as Arshile Gorky, The Artist and His Mother, c. 1926-c. 1942, oil on canvas, 59 15/16 x 50" (152.3 x 127 cm), National Gallery of Art, Washington, D.C., https://www.nga.gov/collection/art-object-page.56935.html.

${ }^{105}$ Egoyan, Ararat, 00:32:48-00:32:50.

${ }^{106}$ Ibid., 01:21:37-01:22:34.
} 
This spectacular confrontation - between an actor playing a historical "character" and a historical "consultant" who is not an "actor" - blurs the boundaries between present and past, actor and spectator, "expert" and storyteller. The film implicates its audience: what stories do we witness, and how do we act (or not act) in response to them? Ussher's words, directed toward Ani, could also apply to the audience of Ararat. Whether one watches or turns away, does nothing or does something, questions or accepts the facts, everyone plays a role in the story of genocide- whether they realize it or not.

Here, Egoyan's film-about-a-film interrogates Ani's roles-as "historical consultant," as a member of the Armenian diaspora, and as a bystander-on the stage of human events. Martin/ Ussher's accusatory question ("[w] ho the fuck are you?") is aimed as much at Ani as at anyone who remains (or remained) oblivious, failing to witness the atrocity at hand. Dori Laub writes of the global failure of witnessing with regards to another historical genocide, the Holocaust:

[I]t was not only the reality of the situation and the lack of responsiveness of bystanders or the world that account for the fact that history was taking place with no witness: it was also the very circumstance of being inside the event that made unthinkable the very notion that a witness could exist, that is, someone who could step outside of the coercively totalitarian and dehumanizing frame of reference in which the event was taking place, and provide an independent frame of reference through which the event could be observed. ${ }^{107}$

In this cataclysmic scene, Martin's character, Clarence Ussher, remains inside the event. From the outside, Ani becomes a belated and unintentional witness - from the perspective of the twenty-first century - to an event in which there was no outside witness, at least not in the moment of the 1915 siege. Here, Egoyan inverts the aphorism of Shakespeare's Jacques in As You Like It: instead of all the world being a stage, here all the stage is the world.

The scene interrogates the very nature of storytelling. The film documents a series of transitions and adaptations: we go from the historical events of 1915 to Clarence Ussher's 1917 memoir to Edward Saroyan's (contemporary, though undated) film to Atom Egoyan's 2002 film. The fact that Egoyan takes the title of Saroyan's film as his title gestures to the impossibility of narrative coherence in the historical wake of the trauma of genocide. Egoyan poses a koan (an impossible riddle): which film - his or Saroyan's (which is arguably also Egoyan's film) - tells the story of Ararat? In the absence of many survivors, perhaps the mountain of Ararat is made to symbolize the witness to the event. One might say that the geographic site of Mount Ararat was, in effect, what Pierre Nora would call a "lieu de mémoire," or "site of remembrance" that is "created by a play of memory and history." ${ }^{108}$ Here, Egoyan directs our attention to the slipperiness of narrative, the impossibility of linear, straightforward storytelling for an event such as genocide.

Ararat uses the mise en abyme structure as a strategy to resist narrative resolution. Each story nested within another story further fractures plot coherence. In doing so, it straddles both time and space, dwelling simultaneously in 1915 and the present day, in Van and in Toronto. In a chiastic logic, the fractured plot makes the present past and the past present. The film's concerns with the impossibility of coherent narration in the wake of trauma raise questions about truth, accuracy, and narrative ethics. By telling several fragmented stories, Egoyan's film resists the narrative closure of a single story. ${ }^{109}$ In doing so, it offers an alternative mode of storytelling - one that opens possibilities of seeing the world, of seeing history, as a collection of inextricably linked stories within stories. By illuminating narrative dissonance, it refuses to provide the viewer with the asylum of narrative harmony. As director Egoyan reflected on his character, Edward Saroyan, "Edward's film could

\footnotetext{
${ }^{107}$ Dori Laub, "Truth and Testimony: The Process and the Struggle," in Trauma: Explorations in Memory, ed. Cathy Caruth 1st ed. (Baltimore: Johns Hopkins University Press,1995), 66.

${ }^{108}$ Pierre Nora, “Between Memory and History: Les Lieux de Mémoire," Representation, no. 26 (Spring, 1989), 19.

${ }^{109}$ Egoyan, Ararat, 115 mins. In 2007, Egoyan drew from the legacy of the 1919 silent film about Aurora Mardiganian, who, as it has been previously noted, has been called the "Anne Frank" of the Armenian genocide, in a visual installation entitled Auroras, in which seven different women of various ethnic backgrounds recite passages from Ravished Armenia, in effect suggesting what Timothy Long has called a "chorus, a resistant 'community of witnessing."' Quoted in Timothy Long, "Atom Egoyan's Auroras: A Chorus of Witnesses," in Testimony and Trauma: Engaging Common Ground, ed. Christina Santos et al. (Leiden and Boston: BRILL, 2019), 289.
} 
never tell a proper narrative, such there's no conclusion to his story."110 In fact, Ararat suggests that the story of genocide is one that is impossible to tell coherently. Nearly a decade later, the work of a Rwandan filmmaker would suggest a similar conclusion.

\section{Anything but Black and White: Grey Matter}

Directed by Rwandan filmmaker Kivu Ruhorahoza, Matière Grise (Grey Matter) is a cinematic portrait of an artist. The 2011 film depicts a young Rwandan director's attempt to create a cinematic portrait of the 1994 genocide. ${ }^{111}$ Like Ararat, it relies on the narrative scaffolding of mise en abyme. Ruhorahoza intertwines three plotlines, which are, like a Matryoshka doll, nestled within one another. It is the story of Balthazar (Hervé Kimenyi), a young Rwandan director in Kigali struggling to find the financial and emotional reserves to make a movie about the genocide, that bookends the film. Balthazar's film, which he dreams of producing if he can obtain the funds, is called The Cycle of the Cockroach. ${ }^{112}$ The two acts of The Cycle of the Cockroach comprise Matière Grise's other two interconnected narratives: one is the story of Yvan (Ramadhan Shami Bizimana) and Justine (Ruth Shanal Nirere), two young adult siblings orphaned by the genocide and haunted by its ghosts several years later. ${ }^{113}$ The other is the story of an unnamed member (Jean Paul Uwayezu) of the Interahamwe, or Hutu killing squads, during the 1994 genocide as he rapes and murders Tutsis. ${ }^{114}$ While the siblings find some sort of healing through both Yvan's therapeutic painting and the act of burying their parents' remains, the film ultimately suggests that their wounds will never heal. ${ }^{115}$ Matière Grise, which switches between French and Kinyarwanda, the country's national language, defies chronological order and withholds any promise of a peaceful future-in effect, prohibiting either spiritual uplift or closure. Harmonizing narratives are unwelcomed here.

Throughout, the film's mise en abyme framework defamiliarizes the very nature of storytelling through its juxtaposition of past and present, real and surreal. More specifically, it interrogates the possibility of representing genocide through a jarring narrative choice: it makes literal a deadly metaphor-inyenzi, or "cockroach," the epithet used against the Tutsi population leading up to and during the 1994 genocide. In other words, in a shockingly obscene gesture, the film takes an ethnic slur, meaning "cockroach," at its face value, substituting actual cockroaches in the place of human beings. Before the insects appear on screen, however, the film contextualizes the ethnic slur and accompanying dog whistles - many of which were transmitted over national radio. In Act I of Balthazar's imagined film, The Cycle of the Cockroach, a radio emits a mellifluous feminine voice into the room where a lone Interahamwe sits. ${ }^{116}$ The female broadcaster's words coax her listeners to exterminate their neighbors by casting Tutsis out of humanity - "[p]lease show no mercy. A cockroach is not a human being...Please never forget that a butterfly will not come out of a cockroach's egg." ${ }^{117}$ Following this scene, Ruhorahoza goes on to make these words literal: he replaces certain human beings - members of the Tutsi ethnic group-with cockroaches. In doing so, he exposes the twisted logic of genocidal thought.

In the same vein as avant-garde French playwright Antonin Artaud, Ruhorahoza engages in what might be called "a theater of cruelty" in which bodily gestures and even obscene symbols

\footnotetext{
${ }^{110}$ Atom Egoyan, "In Other Words: Poetic Licence and the Incarnation of History," University of Toronto Quarterly 73, no. 3 (July 2004), 896

${ }^{111}$ Kivu Ruhorahoza, dir., Matière Grise [Grey Matter] (Scarab Studio Films, 2011), 110 mins.

112 Ibid.

${ }^{113}$ Ibid., 00:39:51

${ }^{114}$ Ibid., 00:23:40-00:39:50.

115 Ibid., 110 mins.

${ }^{116}$ Along with publishing the "Ten Commandments of the Hutu," in the Hutu publication Kangura (“Wake Up!”) in 1990, four years prior to the beginning of the 1994 genocide, see Power, Problem from Hell, 338-339, Hutu extremists leaders also commandeered the RTLM (Radio Télévision Libre Mille Collines) radio station in order to propagate hate speech and ultimately exhort fellow Hutus to exterminate Tutsis. See Power, Problem from Hell, 331-339. For more on the role of Rwandan media - specifically propaganda in newspaper and radio-in inciting the 1994 genocide, see Alison Des Forges, "Leave None to Tell the Story: Genocide in Rwanda" (New York: Human Rights Watch, 1999), 75-114, accessed July 23, 2020, https://www1.essex.ac.uk/armedcon/story id/Leave\%20None $\% 20$ to $\% 20$ tell $\% 20$ the $\% 20$ story- $\% 20$ Genocide\%20in\%20Rwanda.pdf.

${ }^{117}$ Ruhorahoza, Matière Grise, 00:25:10-00:25:23.
} 
overtake language. ${ }^{118}$ More precisely, his character Balthazar enlists surrealism in his own film to expose the grotesque and irrational nature of genocide. Nestled in the middle of Gray Matter, during Balthazar's dream of his own feature film, a Hutu Interahamwe death squad member raves at a lone cockroach after trapping it in a glass jar. ${ }^{119}$ Later, just as Balthazar envisioned in a conversation with his friend at the bar, the camera frames the Interahamwe's buttocks and groin thrusting violently above the cornered insect, which serves as a visual metonym for the so-called inyenzi, the Tutsi victim. ${ }^{120}$ The absurdity of the situation confounds the nightmarish and inexplicable nature of the genocide's destruction that dehumanized its victims. The fact that the film springs from a dream suggests a surreal, unconscious quality that cannot be encompassed by the conventions of realism. Reality is, in fact, a nightmare.

Through the story of Balthazar, who envisions the film of Justine and Yvan, Matière Grise also criticizes the local film industry's indifference and even hostility toward addressing the past. When Balthazar approaches a Rwandan government official to request funding for his film, the bureaucrat discounts the importance of any art that touches on the genocide, saying, "look, I'm sorry, but your story is kind of irrelevant to us. It's a story you could say that's not really important."121 The official then tells Balthazar that he welcomes public health awareness films about HIV and gender-based violence prevention, thus precluding any room for further conversation. This scene implicitly exposes the film industry's - and the public's - disinterest and apathy in films about the genocide, a topic relegated to a lower status in the taxonomy of public awareness. Forced to borrow from a loan shark to finance his film, Balthazar must reckon with the forces-both financial and political-that stand as barriers to the realization of his cinematic dream. The chasm between the film Balthazar wants to make and the ones that are funded underscores not only the problem of representation but also the more logistical question of funding. The name of his film, The Cycle of the Cockroach, suggests a cyclical nature of violence. If we are going in circles, then the mise en abyme structure might be able to break the pattern - or at least temporarily pause it.

\section{New World Genocide: Even the Rain}

While Matière Grise, ${ }^{122}$ and Ararat ${ }^{123}$ address collective violence that occurred during the twentieth century, Spanish director Icíar Bollaín's También La Lluvia (Even the Rain) turns to an even more historically distant genocide. It considers the legacy of colonialism in present-day Bolivia, where Mexican director Sebastián (Gael García Bernal) and Spanish producer Costa (Luis Tosar) are shooting a film about the violence left in the wake of the arrival of Christopher Columbus in the "New World" in 1492. ${ }^{124}$ Underscoring the theme of environmental injustice (based on the Cochabamba Water War of 1999-2000), Bollaín's film refracts a local water problem as remnant of structural violence. ${ }^{125}$

Through its cinematographic juxtaposition of color with black-and-white, one of the film's first scenes illuminates the ethical minefield that accompanies the cinematic narration of a historical trauma such as genocide. En route to the film site, director and producer vigorously debate the pros and cons of filming in Bolivia, which, as Costa exclaims with an attention to the market economy of film production, is "full of starving natives, and that means thousands of extras." 126 Like in Matière Grise, in the logic of national film production, capitalism reigns supreme when it comes

\footnotetext{
${ }^{118}$ In his manifesto, Artaud describes the "theater of cruelty" as, among other things, transcending the limits of language: "It ultimately breaks away from the intellectual subjugation of language, by conveying the sense of a new and deeper intellectuality which hides itself beneath the gestures and signs, raised to the dignity of particular exorcisms." Antonin Artaud, The Theater and Its Double, trans. Mary Caroline Richards (New York: Grove Press, Inc., 1958), 91. 
to stories that are told (or not told) about genocide. Of course, as their assistant María (Cassandra Ciangherotti) notes, Bolivia was far from where Columbus actually landed. Sebastian echoes her concern with "authenticity," pointing out that the extras are Quechua, not Taino. Costa responds with a flattening homogenization of Indigenous persons - "[f]rom the Andes or wherever, they're natives...they're all the same." ${ }^{127}$ Strains of the men's dialogue echoes the mindset ventriloquized through Anton (Karra Elejalde), who later plays the role of Columbus in Sebastián's film, suggesting that the prejudice of the fifteenth century lives on in the twentieth. ${ }^{128}$ Meanwhile, María, whose voice is often silenced-and whose camera is pushed away - by men throughout the film, poses questions to both director and producer that expose the Gordian knots of storytelling - such as the fact that the Quechua extras will not be speaking Taino. ${ }^{129}$

Cinematography mirrors the murkiness of the ethical debate invoked by the characters. The scene pivots from being in color to being filtered through her hand-held camera which captures the world in black and white. This dizzying visual juxtaposition of color draws the viewer's attention to questions of both literal and figurative import, generating a series of questions: in matters of sharing or crafting a story, does the narrative rest on stark binaries (black and white)? (Conversely, this question could be flipped: is it seen in shades of gray?) Or does the frame of the story embrace the nuance and color of the scene at hand? This particular scene underscores how stories, especially those crafted in cinema, are framed-excluding as much as including — and are always shaped by outside forces. Perhaps, as the film suggests, 1492 was not all that long ago.

By tying the plot of Sebastian's film to the sociocultural climate of Cochabamba, También La Lluvia suggests that the legacy of genocide, structural violence, and colonialism imprints presentday South America. The mise en abyme structure of the film fractures time and space, collapsing the chronological distance between 1492 and 2000. It even suggests that the well-intentioned filmmakers are themselves complicit in questionable motives. The film never explicitly suggests that the neoliberal water industry, which privatizes the city's water supply, making a basic resource inaccessible, is genocide. The film does, however, suggest that the water crisis is a manifestation of the structural violence-racism, imperialism, and capitalism - registered and promoted by the genocide Sebastian and his crew are documenting. ${ }^{130}$

The film's use of linguistic anachronism reveals the political and cultural work invoked by a single word. In one scene, Maria, the crew's videographer, interviews some of the cast members about their roles in the film. Curiously, Alberto (Carlos Santos), one of the Spanish actors who is playing Bartholomé de las Casas, the colonist and Dominican friar, recites a speech-allegedly by his character-denouncing the treatment of indigenous peoples that he witnessed in the West Indies. Another actor later brings up the critique that de las Casas wanted to import enslaved Africans, emphasizing a thicket of moral contradictions. ${ }^{131}$ In costume, seen through the black and white lens of Maria's camera, he reads from his notes the words from de las Casas' deathbed - "'II condemn the blindness of those who ignore the genocide and give orders to the world."' $132 \mathrm{He}$ then breaks character, exclaiming to his audience, "[t]his guy was the father of international law, and I'm only in eight scenes!"133 The pronominal slippage between character and actor indicates a fluidity between time and space in the mind of the actor. On the set of the film, as on the streets of Cochabamba, temporal distance between the two eras often collapses.

But what is of particular note here is the use of the word "genocide," or its Spanish cognate, "genocidio" in the quotation attributed to de las Casas. Its existence is impossible. The word did not exist in the sixteenth century. As Raphaël Lemkin's unfinished history of genocide reminds us,

\footnotetext{
${ }^{127}$ Ibid., 00:06:38-00:06:46.

${ }^{128}$ Ibid., 00:20:17-00:20:30.

${ }^{129}$ Ibid., 00:07:13-00:07:25.

${ }^{130}$ Bollaín, También la Lluvia.

${ }^{131}$ Ibid., 00:20:47-00:21:54.

${ }^{132}$ Ibid., 00:16:54-00:17:04.

${ }^{133}$ Ibid., 00:17:04-00:07:13.
} 
Nunn

however, the occurrence of the crime preceded its coinage. ${ }^{134}$ Whether the director (Sebastian and/ or Icíar Bollaín) intended to employ this anachronism is unclear. Still, this chrono-topic sleight of hand allows us to travel in time with a slightly larger lexicon. It magnifies the word's power by forcing the audience - at least those who know the word's etymology and age - to imagine what de las Casas would have said if not that word. The word shoulders an accusation, a story that stands in for violence, extermination, killing, and racial violence. The anachronism emphasizes the amount of cultural, linguistic, and political work that the single word invokes. And its historical inaccuracy also underscores how even well-intentioned filmmakers can revise the lexicon of history.

\section{Parallax Views: The Act of Killing}

Joshua Oppenheimer, an American-born British director based in Denmark, called his 2012 The Act of Killing "a documentary of the imagination." 135 The film excavates the narrative underworld of Indonesian paramilitary leader Anwar Congo, who personally killed at least one thousand people, and his colleagues, who orchestrated the death squads that began in the 1960s in Indonesia. Invited by Oppenheimer to cinematically stage the historical killings on camera, Congo draws from his favorite American cinematic genres - the Western, gangster films, and the musical. Thus, while The Act of Killing is ostensibly about the localized collective violence in Indonesia, the film gestures to a genealogy of violence that may trace its descent from the United States-Hollywood, to be exact. In one scene, Congo (a devoted fan of Elvis Presley, Al Pacino, and John Wayne) identifies how American cinema influenced his methods of killing decades prior. "Each genre has its own methods. Like in the mafia movies, they strangle the guy in the car and dump the body. So we did that too." ${ }^{136}$ Over the course of the documentary, a film within a film emerges. Several times, under Oppenheimer's direction, the camera pans to Congo, who is watching a production of his own film on a television set in his lavish living room.

These moments blur the borders between story and history, make-believe and reality, past and present. This narrative friction generates the most heat in the film's closing minutes, in which Congo, watching himself on a television screen, becomes emotional and asks Oppenheimer, "did the people I tortured feel the way I feel here? I can feel what the people who have been tortured felt." ${ }^{137}$ When the film's director responds, "actually, the people felt far worse because you know it's only a film; they knew they were being killed," Congo insists upon his own suffering - "[b]ut I really felt it, Joshua." 138 Much like the figure of Nazi leader Heinrich Himmler, who, as described by Hannah Arendt in the 1963 book Eichmann in Jerusalem, turned his "instinctive reactions" of "animal pity" on himself, Congo remains blind to the possibility of others' suffering. ${ }^{139}$ In effect, he performs a psychological alchemy that transforms himself from perpetrator to victim.

By watching the director watch Congo, the viewer realizes her own role as spectator of a spectator of a spectator. Once again, the mise en abyme device embeds the viewer within the frame. Because of the shared experience of watching a person watching another person, the audience is positioned similarly to Congo. The film suggests that everyone plays a role, both spectator and actor in the drama. For much of the film, the presence of the United States remains indirect-the favorite Hollywood film genres of Congo, for instance. In one scene, in which Congo reenacts an interrogation, he tells his victim, "although we're only cinema thugs, we want to feel like people

\footnotetext{
${ }^{134}$ Raphaël Lemkin's unpublished history of genocide included an outline for a three-volume History of Genocide, with included three parts: (1) Antiquity, (2) Middle Ages, and (3) Modern Times. The "Modern Times" outline included "Latin America." See Raphaël Lemkin, Lemkin on Genocide, ed. Stephen Leonard Jacobs (Lanham: Lexington, 2014), 18-19.

${ }^{135}$ Joshua Oppenheimer et al., dir., The Act of Killing (Final Cut for Real, 2012), 166 mins; Joshua Oppenheimer, “Build My Gallows High: Joshua Oppenheimer on The Act of Killing," interview by Nick Bradshaw, Sight E Sound Magazine, June 5, 2017, accessed July 15, 2020, https://www.bfi.org.uk/news-opinion/sight-sound-magazine/interviews/buildmy-gallows-high-joshua-oppenheimer-act-killing. In the same interview, Oppenheimer said, "I went looking for embodiments of pure evil, but found ordinary people."

${ }^{136}$ Oppenheimer et al., The Act of Killing, 00:30:12-00:30:23.

${ }^{137}$ Ibid., 02:33:50-02:34:10.

${ }^{138}$ Ibid., 02:34:35-02:34:56.

${ }^{139}$ Hannah Arendt, Eichmann in Jerusalem: A Report on the Banality of Evil, 1st ed. (London: Penguin Classics, 2006), 106.
} 
in the movies."140 The specter of U.S. cinematic archetypes lingers, and in these moments the film forces the spectator to wonder about the extent of the lethality of cultural imperialism. A strange symbiosis between Hollywood and Congo's livelihood emerges when, while revisiting an abandoned movie theater, he reminiscences about his favorite Hollywood films and how he used to work outside the cinema selling black market tickets. He angrily recounts how the Communistshis enemy-banned American movies, thus diminishing the audiences and hence his stream of income - "without them, the gangsters didn't make as much money," his protégé, Herman, chimes in. ${ }^{141}$ Later, Congo makes clear that the movies he watched in the 1960s influenced the method or mood in which he would murder. "Happy" Hollywood films, "like Elvis movies" would inspire him to kill "happily." 142

In other scenes, however, the United States and its relation to violence and genocide is invoked even more explicitly. While riding in the car, Anwar's colleague Adi fiercely responds to an inquiry about committing war crimes. When Oppenheimer asks him about his committing war crimes and hence violating the Geneva Convention, he retorts - "[ $t$ ]he Americans killed the Indians. Has anybody been punished for that? Punish them!" 143 However briefly, the pointing finger is turned away from Congo and his colleagues and back at the director and the American audience. His statements, however discomfiting, make a valid point about the U.S. government's refusal to recognize its own acts of historical genocide. In this moment, Adi shines a mirror away from Indonesia and back at the director and the audience.

Here, cinematography plays with the idea of both literal and figurative mirrors and frames. The scene in which Adi drives a car through town and speaks to Oppenheimer, who asks questions from the back seat, employs a variety of camera angles. Side angles from the passenger seat portray Adi steering the wheel, putting him in profile. Alternatively, rear shots show him doubly: his back on the right side of the screen and his eyes in the rearview mirror. This concatenation of cinematography and mise-en-scène suggests a type of parallax view, in which one character is viewed through multiple angles: simultaneously from behind and, thanks to the mirror, from the front. The formal frames in the shot-the rearview mirror, the car windows-dovetail with the content of Adi's speech. ${ }^{144}$ In acrobatic acts of sophistry, he justifies his history of violence:

The Geneva Conventions may be today's morality, but tomorrow we'll have the Jakarta Conventions and dump the Geneva Conventions. 'War crimes' are defined by the winners. I'm a winner. So I can make my own definition. Ineedn't follow the international definitions. ${ }^{145}$

According to his own moral cosmology, all definitions are a question of context and framing. Today's convention is tomorrow's history. Words such as "war crimes" and "convention" can be discarded, exchanged, and made anew.

\section{The Harm in Harmonizing}

This analysis of Hollywood's harmonizing narratives-most famously, the adaptation of Anne Frank's diary and its cinematic kindred-shows us that these films pose their own set of dangers. They make false promises. By concluding on an optimistic note emphasizing human goodness,

${ }^{140}$ Oppenheimer et al., The Act of Killing, 02:13:47-02:13:55. Oppenheimer has written about the influence of Hollywood on Congo: "I was intrigued by this relationship between cinema and killings, although I had no idea it would be so deep. Not only did Anwar and his friends know and love the cinema, but they dreamed of being on the screen themselves, and styled themselves after their favorite characters. They even borrowed their methods of murder from the screen." See Joshua Oppenheimer, "Background," The Act of Killing, accessed September 5, 2019, http://theactofkilling.com/ background/.

${ }^{141}$ Oppenheimer et al., The Act of Killing, 00:16:56-00:16:59.

${ }^{142}$ Ibid., 00:17:10-00:18:10.

${ }^{143}$ Adi explains to Oppenheimer, "I don't necessarily agree with those international laws. When Bush was in power, Guantanamo was right. Saddam Hussein had weapons of mass destruction. That was right according to Bush, but now it's wrong." Oppenheimer et al., The Act of Killing, 01:10:16-01:11:04.

${ }^{144}$ The motifs of eyes and sight are explored further in Joshua Oppenheimer, The Look of Silence (Final Cut for Real, 2014), 103 mins.

${ }^{145}$ Oppenheimer et al., The Act of Killing, 01:10:34-01:11:05. 
they implicitly occlude the violence of the past. As Bruno Bettelheim pointed out several decades ago in reference to U.S. adaptations of Frank's diary, the rose-colored logic of such narratives denies the reality of evil in the world - "[i]f all men are basically good...then indeed we can all go on with life as usual and forget about Auschwitz." 146 Of course, literary and visual cultures cannot legally prevent mass atrocities. They can, however, shape collective understandings of human rights violations and the possibilities of political change. It seems that each time films such as Hotel Rwanda $a^{147}$ or Schindler's List ${ }^{148}$ claim to remember history, they also abet amnesia. Indeed, these films are spectacular; they prompt their spectators to look. Ironically, with each linear, teleological plot concluding in harmonizing uplift, we appear to be going in circles. As investigative journalist Linda Melvern writes of Hotel Rwanda, "there is an inherent danger in repackaging recent history for Hollywood because distortion can creep into the accepted version of events, and fiction readily becomes established fact." ${ }^{149}$ Moreover, the risk is that the representations in these films may discourage spectators from recognizing and acting in the presence of future atrocities.

Critics, no doubt, will respond with objections. For instance, didn't adaptations of Frank's diary serve a purpose in terms of transitioning from the era of near silence about the Holocaust in the United States to growing awareness that began to increase, as some scholars have noted, in the 1970s? Perhaps. After all, as historian Peter Novick has written, "every generation frames the Holocaust, represents the Holocaust, in ways that suit its mood." ${ }^{\prime 150}$ But we inhabit a different generation than that of George Stevens. In the realm of political rhetoric, the promise of never again, however empty, is invoked with regularity by leaders such as presidents Carter, Reagan, and Clinton, suggesting a collective awareness of select genocides of the past. ${ }^{151}$ In the United States, collective and institutional awareness of genocide and the Holocaust is greater than it was in the immediate postwar years, with curricula in several states dedicated to the topic (though recent studies indicate a gap in basic knowledge among U.S. adults, a trend especially pronounced among millennials). ${ }^{152}$ Since its dedication in 1993, more than 44 million people have visited the United States Holocaust Memorial Museum on the National Mall in Washington, D.C., at least twentyfour percent of whom were school children and approximately ninety percent of whom were nonJewish. ${ }^{153}$ But as I have shown, the predominant narrative patterns - from The Killing Fields ${ }^{154}$ to Schindler's List ${ }^{155}$ to First They Killed My Father ${ }^{156}$ to The Promise ${ }^{157}$-remain more or less stuck in the framing conventions that suited collective awareness of the Holocaust in the 1950s. If Stevens made his film today, he should have kept his original final scene in which his protagonist was swaying in the fog. He could have embraced the narrative dissonance. Some of his contemporaries, such as director Sidney Lumet, chose to do so in his 1964 film The Pawnbroker, ${ }^{158}$ notable for its use of footage of the concentration camps introduced through the flashbacks of its protagonist, Sol

\footnotetext{
${ }^{146}$ Bettelheim, The Ignored Lesson of Anne Frank, 46.

${ }^{147}$ George, Hotel Rwanda.

${ }^{148}$ Spielberg, Schindler's List.

${ }^{149}$ Linda Melvern, "Hotel Rwanda - Without the Hollywood Ending I Linda Melvern," The Guardian, November 17, 2011, accessed April 10, 2020, https://www.theguardian.com/commentisfree/2011/nov/17/hotel-rwanda-hollywood-ending.

${ }^{150}$ Novick, The Holocaust in American Life, 120.

${ }^{151}$ For examples of such promises and vows from U.S. leaders, see United States Holocaust Memorial Museum, "Museum Press Kit: Facts and Figures-United States Holocaust Memorial Museum," last updated June 2019, accessed March 6, 2020, https://www.ushmm.org/information/press/press-kits/united-states-holocaust-memorial-museum-press-kit and Power, Problem From Hell, xxi.

${ }^{152}$ Maggie Astor, "Holocaust Is Fading from Memory, Survey Finds," New York Times, April 12, 2018, accessed June 19, 2019, https://www.nytimes.com/2018/04/12/us/holocaust-education.html.

153 “Museum Press Kit: Facts and Figures-United States Holocaust Memorial Museum," United States Holocaust Memorial Museum, last updated June 2019, accessed March 6, 2020, https://www.ushmm.org/information/press/ press-kits/united-states-holocaust-memorial-museum-press-kit.

${ }^{154}$ Joffé, The Killing Fields.

${ }^{155}$ Spielberg, Schindler's List.

${ }^{156}$ Jolie, First They Killed My Father.

${ }^{157}$ George, The Promise.

${ }^{158}$ Sidney Lumet, The Pawnbroker (Landau Company, The Pawnbroker Company, 1966), 116 mins.
} 
Nazerman (Rod Steiger). ${ }^{159}$ In an adaptation of Edward Lewis Wallant's novel about a Holocaust survivor living in Harlem, the film denies its audience an uplift; as film historian Annette Insdorf writes, "by the end of the film," Sol himself is "a living corpse" and "a broken pawn."160

Most likely, harmonizing narratives about historical genocide are here to stay. But Hollywood could gain valuable lessons from the fractured, dissonant narratives of films such as Ararat, ${ }^{161}$ Matière Grise, ${ }^{162}$ También la Lluvia, ${ }^{163}$ and The Act of Killing. ${ }^{164}$ For instance, we need more moments like the one in Hotel Rwanda in which Rusesabagina debates the merits of broadcasting carnageslivers of time where the viewers must hold a mirror to themselves. The scene raises a question: Is seeing such footage of carnage a good thing if people will just go back, as the photojournalist says, "to eating their dinners"165 - or, even worse, to emulate it, as in The Act of Killing? By holding a mirror to the audiences, however briefly, such scenes could prompt questions that hold up outside the theater. The self-interrogation that these moments potentially catalyze might help to puncture the stubborn optimism of these films' endings-rose-colored reunions and anthems of optimism. The rays of hope proffered in these harmonizing narratives can blind people to the political implications of the situations before them, often playing out simultaneously elsewhere on the planet. How long will it be before we see a Hollywood film about the genocide of the Rohinga people, probably starring a Western hero, that ends on an regretful yet optimistic note?

But as a film such as Ararat ${ }^{166}$ demonstrates, stories of genocide do not have to be told this way. I have shown how Egoyan, Ruhorahoza, Bollaín, and Oppenheimer employ the mise en abyme as a mode to both resist the Hollywood hegemony of harmonizing narratives and suggest alternative means of storytelling. While this narrative mode may be relatively rare within the genre of genocide cinema, it is significant because of the ways it dismantles and criticizes dominant modes of storytelling. For instance, Ararat queries, portrays, and exposes the contested nature of memory of the events of 1915, as evident in the "heated debates" and "turmoil" surrounding the reception of Egoyan's 2002 film in Turkey, where, as Özlem Köksal noted, the "ongoing dominant discourse" is a "denialist" one. ${ }^{167}$ We watch the director stage scenes. We watch the historical consultant contest inaccuracies. We watch the characters watch themselves in the movie theater. The mise en abyme is, in the words of the literary critic Lucien Dällenbach, "the mirror in the text," throwing the spectator's reflection back at herself. ${ }^{168}$ This nesting of stories within stories forces us to question our own role as characters, as voyeurs, as actors. It prompts us to notice the narratives

\footnotetext{
${ }^{159}$ However, as film critic Bosley Crowther points out in The New York Times review, the movie did remove "the detail of the medical experiments upon the hero by the Nazis" that appeared in Edward Lewis Wallant's 1961 novel of the same name. Bosley Crowther, "'The Pawnbroker' Opens at 3 Theaters; Rod Steiger Creates a Tragic Character Camera Seeks Worst Aspects of Harlem," New York Times, April 12, 1965, 51, accessed July 15, 2020, https://www.nytimes. com/1965/04/21/archives/screen-the-pawnbroker-opens-at-3-theaters-rod-steiger-creates-a.html.

${ }^{160}$ Insdorf, Indelible Shadows, 31. For more on the history and adaptation of The Pawnbroker, especially in regard to the representations of African American and Jewish experiences in Harlem, see Wendy Zierler, "'My Holocaust Is Not Your Holocaust': 'Facing' Black and Jewish Experience in The Pawnbroker, Higher Ground, and The Nature of Blood," Holocaust and Genocide Studies 18, no. 1 (2004), 46-67; Alan Mintz, Popular Culture and the Shaping of Holocaust Memory in America (Seattle; London: University of Washington Press, 2001), 109-125.

${ }^{161}$ Egoyan, Ararat.

${ }^{162}$ Ruhorahoza, Matière Grise.

${ }^{163}$ Bollaín, También la Lluvia.

${ }^{164}$ Oppenheimer et al., The Act of Killing.

${ }^{165}$ George, Hotel Rwanda, 00:43:54-00:44:04.

${ }^{166}$ Egoyan, Ararat.

167 Özlem Köksal, “'Past Not-So-Perfect': Ararat and Its Reception in Turkey,” Cinema Journal 54, no. 1 (2014), 45-46. Köksal notes that many analyses of the film in Turkey were written before people had seen the film and also were "limited to a number of controversial scenes taken out of context, making it easier for such nationalistic discourses to be produced about the film." Köksal, Past Not-So-Perfect, 46. For the director's own reflections on the origins of his film, the nature of memory, and Turkish denial of the Armenian genocide, see Egoyan, In Other Words. For more on the relationship between narrative structure, denial, and dehumanization in Ararat, see Donna-Lee Frieze, "Cycles of Genocide, Stories of Denial: Atom Egoyan's Ararat," Genocide Studies and Prevention 3, no. 4 (August 2008), 243-262.

${ }^{168}$ Dällenbach, The Mirror in the Text, 169-174.
} 
we continue to play out without realizing. Sometimes, such as in a film También La Lluvia, ${ }^{169}$ they also point out the structural violence that continues to perpetuate violence. By exposing the generic seams of Hollywood narratives, these directors shed light on the limits of storytelling in a world where never again so often rings hollow. It is true that the cerebral and esoteric nature of these mise en abyme narratives comes at its own price, both in terms of distribution and narrative coherence. They reach fewer people and can test the patience of viewers. ${ }^{170}$ Still, their collective embrace of dissonance underscores how films such as Schindler's List ${ }^{171}$ or Hotel Rwanda ${ }^{172}$ sacrifice certain narrative opportunities to make stories about genocide more palatable and bearable for predominantly U.S. audiences.

A film such as Ararat reminds us that, whether as a drama, a thriller, or a blockbuster, a complete or coherent representation of historical genocide is impossible. ${ }^{173}$ The charade of doing so - to create a sense of closure, finality, or understanding - is quite dangerous. First, the charade imparts a sense that like Hollywood, the conflicts outside the theater may sort themselves out, eventually offering a harmonizing ending. Second, this sense of closure bestows an unearned sense of comprehension of an event. The words of Claude Lanzmann, the French director of the 1985 documentary Shoah, ${ }^{174}$ expand upon this point. Reflecting on his own attempts to document the truth through cinema, Lanzmann once said that "you cannot precisely engender the Holocaust."175 His statement recognizes the impossibility of fully capturing or documenting the event. Lanzmann reflected on the chasm between truth and falsehood, noting "there is no solution of continuity between the two; there is rather a gap, an abyss, and this abyss will never be bridged." ${ }^{176}$ In a similar way, in telling a story about genocide, a director such as Egoyan gestures to the impossibility of telling the entire story. One cannot precisely engender Van in 1915; or Kigali in 1994; or Cambodia in 1979; or Indonesia in 1966; or Amsterdam in 1944. To return to the etymology of the term, mise en abyme, the narrative of genocide is literally "placed in the abyss" -infinitely so. Neither harmonizing narratives nor mise en abyme can necessarily portray the full horror of genocide, but one version implicates its audience and makes them think while the other forecloses the recognition that history may repeat itself again, in spite of the pledges of never again.

Holocaust survivor Primo Levi famously said, "one single Anne Frank moves us more than the countless others who suffered just as she did but whose faces remain in the shadows." ${ }^{177} \mathrm{He}$ is correct. But a failure to recognize the singularity of Anne Frank-her diary's textured, messy nuances and its broader sociohistorical context-denies the world the full story not only of her life but also of the circumstances of her death. There is hope and goodness in her diary, but there is also curiosity, pride, desire, and even rage toward the evil forces pounding on the doors in the streets below her annex window and refusing entrance to a ship full of refugees. Paradoxically, in their attempts to universalize the story of a Jewish girl in Amsterdam for an American audience, Hollywood and Broadway producers inadvertently denied Frank her particularity - in other words,

\footnotetext{
${ }^{169}$ Bollaín, También la Lluvia.

${ }^{170}$ For instance, The New York Times film critic Stephen Holden praised the film but flagged the intricacy of its plot: "'Ararat,' is hands down the year's most thought-provoking film. But it pays a price for its intricate intellectual gamesmanship. At a certain point fairly early on, its Chinese-box structure begins to seem overly contrived." Quoted in Stephen Holden, "To Dwell on a Historic Tragedy or Not: A Bitter Choice," New York Times, November 15, 2002, E18, accessed July 15, 2020, https://www.nytimes.com/2002/11/15/movies/film-review-to-dwell-on-a-historic-tragedyor-not-a-bitter-choice.html.

${ }^{171}$ Spielberg, Schindler's List.

${ }^{172}$ George, Hotel Rwanda.

${ }^{173}$ Egoyan, Ararat.

${ }^{174}$ Claude Lanzmann, dir., Shoah (British Broadcasting Corporation BBC, Historia, Les Film Aleph, Ministère de la Culture de la Republique Française, 1985), 613 mins.

${ }^{175}$ Claude Lanzmann, "The Obscenity of Understanding: An Evening with Claude Lanzmann," in Trauma: Explorations in Memory, ed. Cathy Caruth, 1st ed. (Baltimore: Johns Hopkins University Press, 1995), 206.

${ }^{176}$ Ibid.

${ }^{177}$ Quoted in Barbara Kirshenblatt-Gimblett and Jeffrey Shandler, eds., Anne Frank Unbound: Media, Imagination, Memory (Bloomington: Indiana University Press, 2012), 312.
} 
precisely what made her so human. ${ }^{178}$ By attempting to pigeonhole her into a generic mold - a dreamy, sweet, lovesick teenager reminiscent of those in popular American cinema-Hollywood stripped her of her individuality: her descriptions of her anatomy, her rage, her sensuality desire, and her religious practices. In other words, the true Anne Frank, or at least the one she presented to Kitty, was erased. We owe it to Frank to unabridge the narrative of her narrative. The American adaptations of her diary show us that the stakes of literary and cinematic adaptation are high because if we do not pay attention to them, we risk forgetting to remember inconvenient, uncomfortable truths. By implicitly promising a future free of the crimes of the past, Hollywood versions of these stories perpetuate amnesia and lure viewers into a sense of political complacency. All too often, to harmonize is to harm.

\section{Acknowledgements}

This article benefited from the support, perspective, and suggestions of many: the anonymous peer reviewers, Priscilla Wald, James Dawes, Wesley Hogan, Aarthi Vadde, Tsitsi Jaji, Christine Ryan, Gabriella Levy, Emma Davenport, and Renée Ragin.

\section{Bibliography}

Apfel, Oscar, dir. Ravished Armenia. Produced by William Selig. First National Pictures, 1919.

Arendt, Hannah. Eichmann in Jerusalem: A Report on the Banality of Evil. First. London: Penguin Classics, 2006.

Artaud, Antonin. The Theater and Its Double. Translated by Mary Caroline Richards. Grove Press, Inc.: New York, 1958.

Astor, Maggie. "Holocaust Is Fading From Memory, Survey Finds." The New York Times, April 12, 2018. Accessed June 19, 2019. https://www.nytimes.com/2018/04/12/us/holocausteducation.html.

Balakian, Peter. The Burning Tigris: The Armenian Genocide and America's Response. New York: HarperCollins, 2003.

Baron, Lawrence. Projecting the Holocaust into the Present: The Changing Focus of Contemporary Holocaust Cinema. Lanham: Rowman \& Littlefield Publishers, 2005.

Bettelheim, Bruno. “The Ignored Lesson of Anne Frank." Harper's Magazine, November 1, 1960, 45-50.

Bollaín, Icíar, dir. También La Lluvia. [Even the Rain]. Vitagraph Films, 2010.

Casteel, Sarah Phillips. "Writing Under the Sign of Anne Frank: Creolized Holocaust Memory in Michelle Cliff and Caryl Phillips." Modern Fiction Studies 60, no. 4 (December 29, 2014), 796-820. Doi: 10.1353/mfs.2014.0051

Chandler, Michael Alison. "School System in Va. Won't Teach Version of Anne Frank Book." Washington Post, January 29, 2010. Accessed May 14, 2019. http://www.washingtonpost. com/wp-dyn/content/article/2010/01/28/AR2010012804001.html.

Cliff, Michelle. Abeng. First Plume Printing ed. New York: Plume, 1995.

Cole, Tim. Selling the Holocaust: From Auschwitz to Schindler; How History Is Bought, Packaged and Sold. 1st ed. New York: Routledge, 2000.

Coutts, Angela. "Remembering Anne Frank in Japan: Akazome Akiko's Otome No Mikkoku/ The Maiden's Betrayal." Contemporary Women's Writing 8, no. 1 (March 2014), 71-88. Doi: $10.1093 / \mathrm{cww} / \mathrm{vpt} 002$

\footnotetext{
${ }^{178}$ This reflexive aversion to graphic, discomfiting details continues into the twenty-first century. The content of the restored fiftieth anniversary "definitive" version of the diary continues to upset U.S. readers. As recently as 2010, the school system of Culpeper County, Virginia, banned the restored fiftieth anniversary "definitive" version due to "complaints about its sexual content and homosexual themes." For many years, the 1955 play version had been a part of the eight-grade curriculum. See Michael Alison Chandler, "School System in Va. Won't Teach Version of Anne Frank Book," Washington Post, January 29, 2010, accessed May 14, 2019, http://www.washingtonpost.com/wpdyn/content/article/2010/01/28/AR2010012804001.html). In 2013 there was a call to ban the diary in Northville school district in Michigan after a student's mother objected to Frank's "pretty graphic" description of her anatomy, which made her daughter "uncomfortable." See, Alison Flood, "Anne Frank's Diary in US Schools Censorship Battle," The Guardian, May 7, 2013, accessed May 14, 2019, https://www.theguardian.com/books/2013/may/07/anne-frank-diaryus-schools-censorship.
} 
Nunn

Cronin, Paul, ed. George Stevens: Interviews. Jackson: University Press of Mississippi, 2004.

Crowder-Taraborrelli, Tomás F., and Kristi M. Wilson, eds. Film and Genocide. Madison, Wisconsin: The University of Wisconsin Press, 2012.

Crowther, Bosley. "'The Pawnbroker' Opens at 3 Theaters; Rod Steiger Creates a Tragic Character Camera Seeks Worst Aspects of Harlem." The New York Times, April 21, 1965, 51. Accessed July 15, 2020. https://www.nytimes.com/1965/04/21/archives/screen-the-pawnbrokeropens-at-3-theaters-rod-steiger-creates-a.html.

. "Straight to the Heart; 'The Search' a Great Film Drama With Vital Appeal." New York Times, April 4, 1948, 1. https://www.nytimes.com/1948/04/04/archives/straight-to-theheart-the-search-a-great-film-drama-with-vital.html?searchResultPosition=4.

Dällenbach, Lucien. The Mirror in the Text. Translated by Jeremy Whiteley and Emma Hughes. Chicago: University of Chicago Press, 1989.

Des Forges, Alison. "Leave None to Tell the Story:" Genocide in Rwanda. New York: Human Rights Watch, 1999, 6-591. Accessed July 23, 2020. https://www1.essex.ac.uk/armedcon/story id/ Leave $\% 20$ None $\% 20$ to $\% 20$ tell $\% 20$ the $\% 20$ story-\%20Genocide $\% 20$ in $\% 20$ Rwanda.pdf.

Dmytryk, Edward, dir. The Juggler. Columbia Pictures, 1953.

Dokotum, Okaka Opio. "Re-Membering the Tutsi Genocide in Hotel Rwanda (2004): Implications for Peace and Reconciliation." African Conflict \& Peacebuilding Review 3, no. 2 (Fall 2013), 129-150. Doi: 10.2979/africonfpeacrevi.3.2.129

Doneson, Judith. "The American History of Anne Frank's Diary." Holocaust and Genocide Studies 2, no. 1 (1987), 149-160. Doi: 10.1093/hgs/2.1.149

Douglas, Lawrence. "Film as Witness: Screening Nazi Concentration Camps before the Nuremberg Trials." The Yale Law Journal 105, no. 2 (November 1995), 449-481. Doi: 10.2307/797126

Dworkin, Martin S. "In Other Words: Poetic Licence and the Incarnation of History." University of Toronto Quarterly 73, no. 3 (Summer 2004), 886-905. Doi: 10.3138/utq.73.3.886

. "The Vanishing Diary of Anne Frank." The Critic 18, no. 4 (February 1, 1960), 15-16, 76-78.

Egoyan, Atom, dir. Ararat. Miramax, 2002.

--------. "In Other Words: Poetic Licence and the Incarnation of History," University of Toronto Quarterly 73, no. 3 (July 2004), 886-905

Erbelding, Rebecca, and Gertjan Broek. "German Bombs and US Bureaucrats: How Escape Lines from Europe Were Cut Off." Anne Frank House \& United States Holocaust Memorial Museum, July 2018. Accessed July 15, 2020. https://www.annefrank.org/es/downloads/ filer public/94/3e/943ed001-ba04-4e2a-9360-e642d0d82006/ushmm afh july2018.pdf.

Filipovic, Zlata. Zlata's Diary: A Child's Life in Wartime Sarajevo. Translated by Christina PribichevichZorie. Reissue. New York: Penguin Books, 2006.

Flood, Alison. "Anne Frank's Diary in US Schools Censorship Battle." The Guardian, May 7, 2013. Accessed May 14, 2019. https://www.theguardian.com/books/2013/may/07/anne-frankdiary-us-schools-censorship.

Frank, Anne. The Diary of a Young Girl. Edited by Otto H. Frank. Translated by Susan Massotty. New York, N.Y.: Anchor Books, 1996.

Franklin, Ruth. "How Should Children's Books Deal with the Holocaust?" The New Yorker, July 16, 2018. Accessed July 15. https://www.newyorker.com/magazine/2018/07/23/how-shouldchildrens-books-deal-with-the-holocaust.

Frieze, Donna-Lee. "Arshaluys Mardigian/Aurora Mardiganian: Absorption, Stardom, Exploitation, and Empowerment." In Women and Genocide: Survivors, Victims, Perpetrators, edited by Elissa Bemporad and Joyce W. Warren, 58-76. Bloomington: Indiana University Press, 2018. Doi: $\underline{10.2307 / j . c t v g d 2 j m .8}$

------. "Cycles of Genocide, Stories of Denial: Atom Egoyan's Ararat." Genocide Studies and Prevention 3, no. 2 (August 2008), 243-62. Doi: 10.1353/gsp.2011.0048

George, Terry, dir. Hotel Rwanda. United Artists, Lions Gate Films, 2004.

-----. The Promise. Open Road Films, 2016.

Gilbert, Shirli. "Anne Frank in South Africa: Remembering the Holocaust During and After Apartheid." Holocaust and Genocide Studies 26, no. 3 (December 23, 2012), 366-393. Doi: $10.1093 / \mathrm{hgs} / \mathrm{dcs} 058$ 
Goldman, Eric A. The American Jewish Story through Cinema. 1st ed. The Jewish History, Life, and Culture Series. Austin: University of Texas Press, 2013.

Gorky, Arshile. The Artist and His Mother. c. 1926-c. 1942. Oil on canvas, 59 15//16 x 50" (152.3 x 127 $\mathrm{cm})$. National Gallery of Art

Harris, Mark. Five Came Back: A Story of Hollywood and the Second World War. New York: Penguin, 2014.

Holden, Stephen. "To Dwell on a Historic Tragedy or Not: A Bitter Choice." The New York Times, November 15, 2002, E18. Accessed July 15, 2020. https://www.nytimes.com/2002/11/15/ movies/film-review-to-dwell-on-a-historic-tragedy-or-not-a-bitter-choice.html.

Hron, Madelaine. "Genres of 'Yet Another Genocide': Cinematic Representations of Rwanda." In Film and Genocide, edited by Kristi M. Wilson and Tomás F. Crowder-Taraborrelli, 133-153. Madison, Wisconsin: The University of Wisconsin Press, 2012.

Insdorf, Annette. Indelible Shadows: Film and the Holocaust. 3rd ed. Cambridge; New York: Cambridge University Press, 2002. Doi: $10.1017 /$ CBO9780511615276

Joffé, Roland, dir. The Killing Fields. Warner Brothers, 1984.

Jolie, Angelina, dir. First They Killed My Father. Netflix, 2017.

Kazan, Elia, dir. Gentleman's Agreement. Produced by Darryl F. Zanuck. Twentieth Century Fox, 1947.

Keneally Thomas. Schindler's Ark. London: Hodder and Stoughton, 1982.

Kirshenblatt-Gimblett, Barbara, and Jeffrey Shandler, eds. Anne Frank Unbound: Media, Imagination, Memory. Bloomington: Indiana University Press, 2012.

Köksal, Özlem. "'Past Not-so-Perfect': Ararat and Its Reception in Turkey." Cinema Journal 54, no. 1 (2014), 45-64. Doi: $10.1353 / c i .2014 .0069$

Kramer, Stanley, dir., Judgement at Nuremberg. Roxlom Films Inc., 1961.

LaCapra, Dominick. Writing History, Writing Trauma. Baltimore: Johns Hopkins University Press, 2001.

Lanzmann, Claude, dir. Shoah. British Broadcasting Corporation BBC, Historia, Les Film Aleph, Ministère de la Culture de la Republique Française, 1985.

--------. "The Obscenity of Understanding: An Evening with Claude Lanzmann." In Trauma: Explorations in Memory, edited by Cathy Caruth, 1st ed., 200-220. Baltimore: Johns Hopkins University Press, 1995.

Laub, Dori. "Truth and Testimony: The Process and the Struggle." In Trauma: Explorations in Memory, edited by Cathy Caruth, 1st edition., 61-75. Baltimore: Johns Hopkins University Press, 1995.

Lee, Carol Ann. The Hidden Life of Otto Frank. Reprint edition. New York: Harper Perennial, 2003.

Lemkin, Raphaël. Lemkin on Genocide. Edited by Stephen Leonard Jacobs. Lanham: Lexington Books, 2014.

Levin, Meyer. "The Child Behind the Secret Door." The New York Times Book Review, June 15, 1952. Accessed July 15, 2020. https://timesmachine.nytimes.com/ timesmachine/1952/06/15/93375295.html?pageNumber=93.

Long, Timothy. "Atom Egoyan's Auroras: A Chorus of Witnesses." In Testimony and Trauma: Engaging Common Ground, edited by Christina Santos, Adriana Spahr, and Tracy Crowe Morey, 289-307. Leiden and Boston: BRILL, 2019. Doi: 10.1163/9789004391130 015

Lumet, Sidney, dir. The Pawnbroker. Landau Company, The Pawnbroker Company, 1966.

Malkki, Liisa H. "Children, Humanity, and the Infantilization of Peace." In In the Name of Humanity: The Government of Threat and Care, edited by Ilana Feldman and Miriam Ticktin, 58-85. Durham: Duke University Press Books, 2010. Doi: 10.1215/9780822393221-003

Mardiganian, Aurora, and Henry Leyford Gates. Ravished Armenia and the Story of Aurora Mardiganian. Edited by Anthony Slide. Jackson: University Press of Mississippi, 2014.

Melvern, Linda. "Hotel Rwanda - without the Hollywood Ending I Linda Melvern." The Guardian, November 17, 2011. Accessed 10, 2020. https://www.theguardian.com/commentisfree/2011/ nov/17/hotel-rwanda-hollywood-ending.

Mintz, Alan. Popular Culture and the Shaping of Holocaust Memory in America. Seattle; London University of Washington Press, 2001. 
Oxford English Dictionary Online. (Oxford University Press), s.v. "Mise En Abyme." Accessed May 16, 2018. http://www.oed.com/view/Entry/245796.

Moss, Marilyn Ann. Giant: George Stevens, a Life on Film. Madison: University of Wisconsin Press, 2004.

Nora, Pierre. "Between Memory and History: Les Lieux de Mémoire." Representations, no. 26 (Spring 1989), 7-24. Doi: $10.2307 / 2928520$

Nosseck, Max, dir. Singing in the Dark. A.N.O. Productions, 1956.

Novick, Peter. The Holocaust in American Life. Boston: Houghton Mifflin, 1999.

Ondaatje, Michael. Anil's Ghost. New York: Knopf, 2000.

Oppenheimer, Joshua. "Background." The Act of Killing. Accessed September 5, 2019. http:// theactofkilling.com/background/.

. "Build My Gallows High: Joshua Oppenheimer on The Act of Killing." Interview by Nick Bradshaw. Sight \& Sound Magazine, June 5, 2017. Accessed July 15, 2020. https://www.bfi. org.uk/news-opinion/sight-sound-magazine/interviews/build-my-gallows-high-joshuaoppenheimer-act-killing.

Oppenheimer, Joshua, dir. The Look of Silence. Final Cut for Real, 2014.

Oppenheimer, Joshua, Christine Cynn, and Anonymous, dir. The Act of Killing. Final Cut for Real, 2012.

Ozick, Cynthia. "The Misuse of Anne Frank's Diary." The New Yorker, September 29, 1997. Accessed September 6, 2018. https://www.newyorker.com/magazine/1997/10/06/who-owns-annefrank.

Peck, Raoul, dir. Sometimes in April. HBO Films, 2005.

Playhouse 90. Los Angeles. Aired on CBS from 1956-1960.

Power, Samantha. "A Problem from Hell": America and the Age of Genocide. Reprint edition. New York: Basic Books, 2013.

Roosevelt, Eleanor. "Introduction." In Anne Frank: The Diary of a Young Girl. Garden City: Doubleday \& Company, Inc., 1952.

Rosenfeld, Alvin H. The End of the Holocaust. Bloomington, Indiana: Indiana University Press, 2011. Ruhorahoza, Kivu, dir. Matière Grise [Grey Matter]. Scarab Studio Films, 2011.

Rusesabagina, Paul, and Tom Zoellner. An Ordinary Man: An Autobiography. New York: Viking Penguin, 2006.

Sackett, Robert. "Memory by Way of Anne Frank: Enlightenment and Denial Among West Germans, Circa 1960." Holocaust and Genocide Studies 16, no. 2 (September 1, 2002), 243-265. Doi: $10.1093 / \mathrm{hgs} / 16.2 .243$

Schimmel, Noam. "An Invisible Genocide: How the Western Media Failed to Report the 1994 Rwandan Genocide of the Tutsi and Why." The International Journal of Human Rights 15, no. 7 (2010), 1125-1135. Doi: 10.1080/13642987.2010.499728

Shandler, Jeffrey. Jews, God, and Videotape: Religion and Media in America. New York: New York University Press, 2009. Doi: 10.18574/nyu/9780814740675.001.0001

Spielberg, Steven, dir. Schindler's List. Universal Pictures, 1993.

Stevens, George, dir. A Place in the Sun. Paramount Pictures, 1951.

- Giant. Warner Brothers, 1956.

. Nazi Concentration Camps. Documentary Film, 1945.

--------. Penny Serenade. Colombia Pictures, 1941.

-------. Shane. Paramount Pictures, 1953.

-------. Swing Time. RKO Radio Pictures, 1936.

--------. The Diary of Anne Frank. Twentieth Century Fox, 1959.

-------. The More the Merrier. Columbia Pictures, 1943.

--------. The Nazi Plan. 20th Century-Fox, 1945.

. Woman of the Year. Metro-Goldwyn Mayer, 1942.

Tusan, Michelle. "Promises, Promises: The Strange History of Film and the Armenian Genocide." Los Angeles Review of Books, May 25, 2017. Accessed September 16, 2019. https:// lareviewofbooks.org/article/promises-promises-strange-history-film-armenian-genocide/. 
United States Holocaust Memorial Museum. "Museum Press Kit: Facts and Figures - United States Holocaust Memorial Museum." Last updated June 2019. Accessed March 6, 2020. https://www.ushmm.org/information/press/press-kits/united-states-holocaust-memorialmuseum-press-kit.

Ussher, Clarence Douglas, and Grace Higley Knapp. An American Physician in Turkey: A Narrative of Adventures in Peace and War. Boston, Houghton Mifflin, 1917.

Wilson, Katherine. "Anne Frank Abroad: The Emergence of World Atrocity Literature." World Literature Today 87, no. 3 (June 2013), 28-33. Doi: 10.7588/worllitetoda.87.3.0028

Wilson, Kristi M. and Tomás F. Crowder-Taraborrelli, eds. Film and Genocide. Madison, Wisconsin: The University of Wisconsin Press, 2012.

Zayzafoon, Lamia Ben Youssef. "Anne Frank Goes East: The Algerian Civil War and the Nausea of Postcoloniality in Waciny Laredj's 'Balconies of the North Sea."' College Literature 37, no. 1 (2010), 61-80. Doi: 10.1353/lit.0.0091

Zierler, Wendy. "'My Holocaust Is Not Your Holocaust': 'Facing' Black and Jewish Experience in The Pawnbroker, Higher Ground, and The Nature of Blood." Holocaust and Genocide Studies 18, no. 1 (2004), 46-67. Doi: 10.1093/hgs/dch039

Zinnemann, Fred, dir. The Search. Loew's, Inc., 1948.

Zylberman, Lior, and Vicente Sánchez-Biosca. "Reflections on the Significance of Images in Genocide Studies: Some Methodological Considerations." Genocide Studies and Prevention 12, no. 2 (2018), 1-17. Doi: 10.5038/1911-9933.12.2.1620 